\title{
Equatorially Symmetric Impact of the El Niño-Southern Oscillation on the South Asian Summer Monsoon System
}

\author{
Ryuichi KAWAMURA \\ Department of Earth Sciences, Toyama University, Toyama, Japan \\ Tomonori MATSUURA and Satoshi IIZUKA \\ National Research Institute for Earth Science and Disaster Prevention, Tsukuba, Japan \\ (Manuscript received 20 January 2003, in revised form 28 July 2003)
}

\begin{abstract}
A dominant impact of the El Niño-Southern Oscillation (ENSO) on the South Asian summer monsoon interannual variability is identified using the National Centers for Environmental Prediction/National Center for Atmospheric Research reanalysis aided by an ocean general circulation model. It has an equatorially symmetric structure and is most pronounced at the growth phase of ENSO in late summer during the period from the 1960s to mid-1970s when tropospheric biennial oscillation (TBO)-like ENSO dominates. As ENSO develops, an anomalous Walker circulation system over the tropical Indian and Pacific oceans changes from a single-cell regime in summer to a double-cell regime in fall. Meanwhile, rainfall anomalies of an equatorially symmetric structure are induced over the tropical Indian Ocean, accompanied by north-south twin circulation anomalies in the lower troposphere. The northern circulation is dynamically linked with anomalous monsoon rainfall over India especially in late summer. This research suggests that a combination of the wind-evaporation feedback in the Indian Ocean and ocean dynamics in the tropical Pacific is crucial for the regime transition of the anomalous Walker circulation system associated with the TBO-like ENSO. As the seasonality of the ENSO cycle changes before and after the late 1970s, the difference in ENSO impacts between its growth and decay phases may have influenced the ENSO-monsoon relationship and caused its interdecadal change.
\end{abstract}

\section{Introduction}

Previously, it has been well known that the coupling between the South Asian summer monsoon and the El Niño-Southern Oscillation (ENSO) has weakened rapidly in the last two decades (Kumar et al. 1999), which seriously influences the establishment of practical longrange prediction of the monsoon variability. Miyakoda et al. (2000) highlighted the all-India rainfall (AIR) index (Parthasarathy et al. 1995)

Corresponding author: Ryuichi Kawamura, Department of Earth Sciences, Toyama University, 3190 Gofuku, Toyama 930-8555, Japan.

E-mail: kawamura@sci.toyama-u.ac.jp

(C) 2003, Meteorological Society of Japan and five circulation indices: i.e., three monsoon indices defined by Webster and Yang (1992), Kawamura (1998) and Goswami et al. (1999), the tropical-wide oscillation index proposed by Navarra et al. (1999), and the Southern Oscillation index, in terms of the dynamic features of the monsoon and its association with ENSO, and pointed out that before 1976, the correlation coefficients among the six indices were very high. Their result shows that the ENSOmonsoon relationship prior to the late 1970s was very robust. A number of researchers have been trying to clarify why the ENSO-monsoon connection has weakened since the late 1970s. For instance, Chang et al. (2001) proposed a hypothesis that the weakened inverse relation- 
ship between the Indian monsoon rainfall and ENSO might be attributed to the strengthening and poleward shift of the jet stream over the North Atlantic. Ashok et al. (2001) described that the frequent occurrence of intense Indian Ocean dipole mode (Saji et al. 1999) in the last decade plays an important role in the weakening of the ENSO-monsoon correlation.

As for the ENSO-monsoon relationship prior to the late $1970 \mathrm{~s}$, Yasunari $(1990,1991) \mathrm{dem}-$ onstrated lagged correlations between AIR and SSTs in the eastern and western tropical $\mathrm{Pa}-$ cific, based on the data before the mid-1980s, and postulated that anomalous monsoonal heating may play an active role in triggering ENSO events. His pioneering work led to the dispute on two-way interaction between the South Asian summer monsoon and ENSO. Interestingly, Yasunari's lagged correlation map also exhibits a pronounced quasi-biennial oscillation in the monsoon-ENSO system, suggesting that this oscillation links ENSO with the monsoon activity. Meehl (1987) already proposed a conceptual model of such tropospheric biennial oscillation (TBO) and emphasized the crucial role of an anomalous Walker circulation over the tropical Indian and Pacific oceans including local air-sea interactive processes. Using a simple five-box coupled ocean-atmosphere model, Chang and $\mathrm{Li}$ (2000) showed that the TBO is an inherent mode in the monsoon system, resulting from the interactions between northern summer and winter monsoon and the tropical Indian and Pacific oceans. They also stated that the eastern Pacific plays only a passive role in their TBO mechanism, while the South Asian monsoon plays an active role in anomalous tropical east-west circulation over the Asian continent and Pacific Ocean. One may argue that since the TBO has not dominated in the last two decades, the ENSOmonsoon relationship has become weak. It still remains uncertain, however, whether the TBO is independent of ENSO, or is a result of the irregularity of ENSO itself.

This study is a continuation of Kawamura (1998) and Kawamura et al. (2001a, b). It is inferred from their studies that an indirect ENSO impact on the monsoon system at the decay phase of ENSO is significantly different from that at its growth phase. If the seasonality of the ENSO cycle changes before and after the late 1970s, the difference in ENSO impacts between its growth and decay phases may influence the ENSO-monsoon relationship. This is most likely to be a key point for understanding the interdecadal change of those couplings. Although they examined the ENSO-monsoon relationship after the late 1970s, in this study we address the strong relationship prior to the late 1970s and discuss a dominant ENSO impact on the monsoon interannual variability at the growth phase of ENSO on a subseasonal basis, using the National Centers for Environmental Prediction/National Center for Atmospheric Research (NCEP/NCAR) global atmospheric reanalysis dataset (Kalnay et al. 1996), and the Global Ice and SST (GISST) dataset (Parker et al. 1995). An oceanic general circulation model (OGCM) also is used in this study to analyze the mechanisms involved. It should be noted that the interannual variability of the South Asian summer monsoon is examined in terms of broad-scale monsoon circulation rather than monsoon rainfall confined only to the Indian subcontinent.

\section{Model simulation and analysis procedure}

The OGCM used is the version 2 of the Geophysical Fluid Dynamics Laboratory Modular Ocean Model (Pacanowski 1996). The horizontal grid spacing is $1.125^{\circ}$ longitude by $0.5625^{\circ}$ latitude. There are 37 levels in vertical; the upper $400 \mathrm{~m}$ is divided into 25 levels. The model is spun up for 20 years from a static state using Levitus (1982) annual mean temperatures and salinities as initial conditions, and then integrated for 45 years from 1955 to 1999 using surface fluxes obtained from NCEP/ NCAR daily global atmospheric reanalysis data. In this study, only output for the 43-year period from 1957 to 1999 is analyzed. Wind stress and heat fluxes are computed using bulk equations (see Appendix A). Note that model SSTs are used in estimating upward longwave radiation, sensible heat and latent heat fluxes to reduce the bias of the ocean model (Rosati and Miyakoda 1988), since the direct use of the reanalysis fluxes may enhance the model bias. Therefore, the heat fluxes presented in the following sections, which differ significantly from the reanalysis fluxes, depend on both the model and observations. Restoration of the sea surface 
(a)

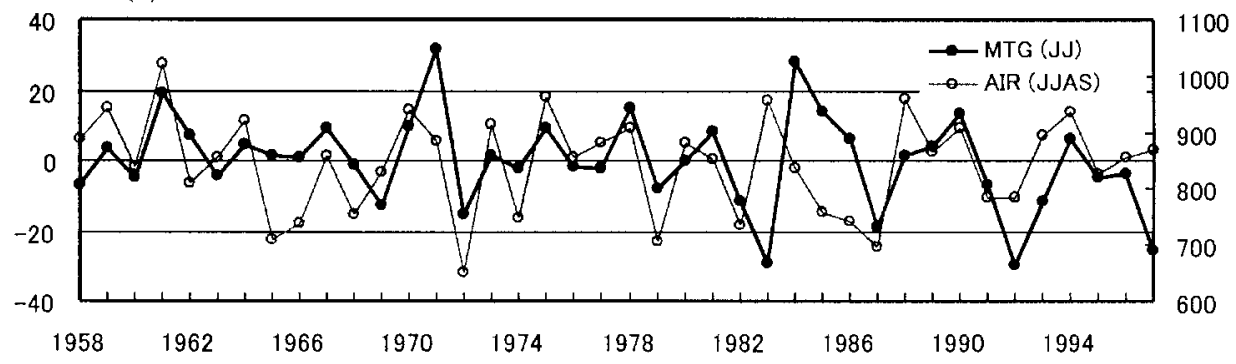

(b)

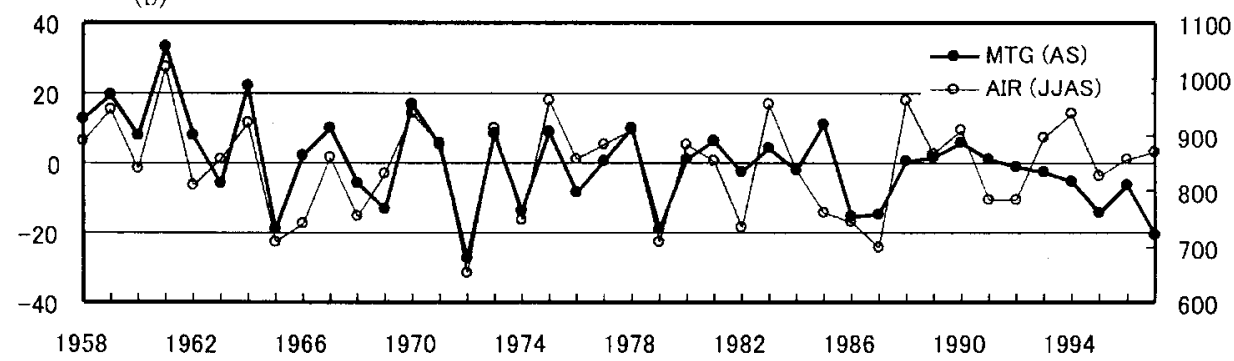

(c)

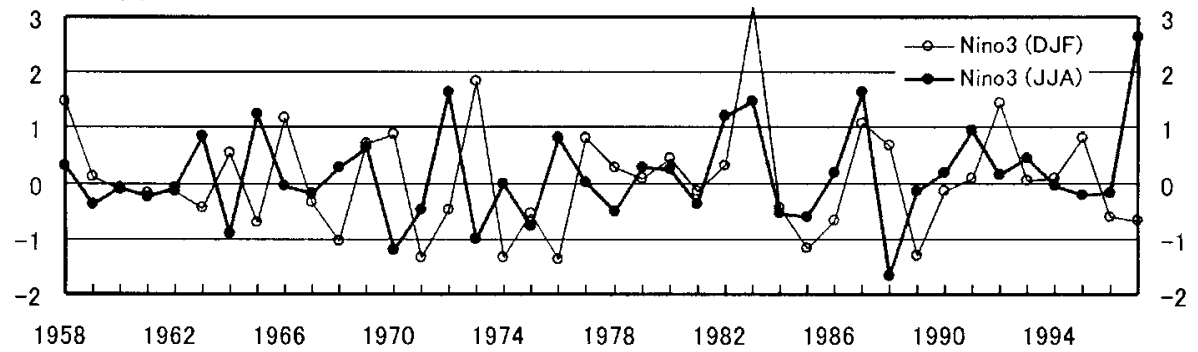

Fig. 1. Interannual time series of (a) June-July (JJ) mean monsoon index and (b) August-September (AS) mean monsoon index. This index proposed by Kawamura (1998) is termed the meridional thermal gradient (MTG) index by Miyakoda et al. (2003). Also shown is time series of JuneSeptember (JJAS) all-India rainfall (AIR). Lower panel (c) indicates time series of DecemberFebruary (DJF) and June-August (JJA) mean SST anomalies averaged for the Nino-3 region. Note that winter 1958 refers to the period from December 1957 through February 1958.

salinity to the climatological monthly mean Levitus (1982) values is used as the surface boundary condition.

Ailikun and Yasunari (2001) postulated that the critical change of the ENSO-monsoon interaction is likely to occur between early and late summers. Based on their findings, we tried to compare June-July (JJ) and August-September (AS) mean monsoon indices in terms of interannual variability. In this study, we adopted Kawamura's (1998) monsoon index. This index is defined as the meridional difference in areaaveraged upper tropospheric $(200-500 \mathrm{hPa})$ thickness between the Tibetan Plateau $\left(50^{\circ}-\right.$ $\left.100^{\circ} \mathrm{E}, 20^{\circ}-40^{\circ} \mathrm{N}\right)$ and the Indian Ocean $\left(50^{\circ}-\right.$ $\left.100^{\circ} \mathrm{E}, 0^{\circ}-20^{\circ} \mathrm{N}\right)$ regions, which is termed the meridional thermal gradient (MTG) index by Miyakoda et al. (2003). They confirm its usefulness as well as Webster and Yang's (1992) index.

Figure 1 shows the interannual time series of the JJ and AS mean MTG indices, together with the June-to-September (JJAS) AIR index and boreal wintertime (December-February) and summertime (June-August) Nino-3 SST indices. Note that winter 1958 refers to the period from December 1957 through February 1958. Looking at the lower panel, it turns out 
that the phase difference between the DJF and JJA Nino-3 SST indices changes significantly before and after the late 1970s. That is, the two SST indices are out of phase with each other during the period from the 1960s to mid-1970s, but those indices tend to be roughly in phase with each other during the period from the late 1970 s to early 1990 s, implying that there is a definite interdecadal modulation of ENSO in terms of its seasonal evolution. Interestingly, MTG (JJ) amplifies with a 4-5 year period after the late 1970s (upper panel), whereas MTG (AS) amplifies with a 2-3 year period before the late 1970s (middle panel), which is also confirmed by a wavelet analysis (see Appendix B). Comparing MTG with Nino-3 SST, MTG (AS) is out of phase with Nino-3 SST (JJA) before the late 1970 s (the cross correlation between the two during a 15-yr period 1962-1976 is -0.90 ), but its relationship is not evident after the late 1970s (the correlation during another 15-yr period 1979-1993 is -0.30). By contrast, MTG (JJ) is out of phase with Nino-3 SST (DJF) in the preceding winter after the late 1970s $(r=-0.77)$. Correlations between MTG and Nino-3 SST indices are given in Table 1. As for the early stage of monsoon season, the MTG (JJ)-ENSO relationship becomes very significant in the last two decades, which has already been investigated by Kawamura (1998) and Kawamura et al. (2001a, b). Thus, we cannot simply state that the ENSOmonsoon relationship becomes weak rapidly in the last two decades, although it is true if AIR is used for the analysis.

Another discernible feature is that prior to the late 1970s, AIR is well correlated with MTG (AS) $(r=0.80)$, but after the late $1970 \mathrm{~s}$ the correlation between the two becomes low $(r=$ 0.58). Of course, AIR and MTG do not necessarily have to coincide with each other because AIR represents anomalous total monsoon rainfall confined only to the Indian subcontinent, while MTG indicates a useful measure of broadscale monsoon circulation anomalies such as Webster and Yang's (1992) index. Nevertheless, the high correlation between the two before the late 1970s must be meaningful in understanding an interdecadal change in the ENSOmonsoon connection. As already known, TBOlike ENSO, dominates before the late 1970s; its turnabout occurs in boreal spring (e.g., Ras-
Table 1. Cross-correlation coefficients between MTG and Nino-3 SST indices before and after the late 1970s. The former period is a $15-\mathrm{yr}$ period 1962-1976, which is highlighted in this study. The latter period is another 15-yr period 1979-1993, which has already been examined in previous studies (Kawamura 1998; Kawamura et al. 2001a, b). Note that Nino3 SST (DJF) is an ENSO index in the winter preceding the summer monsoon season. Asterisk denotes the coefficient with the $1 \%$ level of statistical significance.

\begin{tabular}{|c|c|c|c|c|}
\hline \multirow{2}{*}{} & \multicolumn{2}{|c|}{$\begin{array}{c}\text { Before the late } \\
1970 \text { s }\end{array}$} & \multicolumn{2}{c|}{$\begin{array}{c}\text { After the late } \\
1970 \text { s }\end{array}$} \\
\cline { 2 - 5 } & $\begin{array}{c}\text { MTG } \\
\text { (JJ) }\end{array}$ & $\begin{array}{c}\text { MTG } \\
\text { (AS) }\end{array}$ & $\begin{array}{c}\text { MTG } \\
\text { (JJ) }\end{array}$ & $\begin{array}{c}\text { MTG } \\
\text { (AS) }\end{array}$ \\
\hline $\begin{array}{c}\text { Nino-3 SST } \\
\text { (DJF) }\end{array}$ & -0.16 & 0.43 & $\mathbf{- 0 . 7 7 *}$ & -0.04 \\
\hline $\begin{array}{c}\text { Nino-3 SST } \\
\text { (JJA) }\end{array}$ & $-0.62 *$ & $-\mathbf{0 . 9 0} *$ & $-0.63^{*}$ & -0.30 \\
\hline
\end{tabular}

musson and Carpenter 1982), but after that prolonged ENSO appears frequently, and tends not to terminate in spring. The presence of such two different ENSO regimes is likely to make the ENSO-monsoon connection quite complex.

On the basis of the interannual variations of Nino-3 SST of JJA, we extracted the six coldest events (1964, 1967, 1970, 1971, 1973 and 1975) and the six warmest events $(1963,1965,1968$, 1969, 1972 and 1976) for the 15-yr period 1962-1976 when the MTG (AS)-ENSO relationship is most evident. Since the selected cold and warm events coincide quite with positive and negative signs of MTG (AS), respectively, we can regard the above two categories as the strong monsoon/cold event and weak monsoon/ warm event categories. As for that period, we confirmed that composites yield very similar results even though MTG (AS) is used for the analysis (not shown). Following the above categories, we simply make composite analyses with respect to major variables such as SST, wind stress, latent heat flux, rainfall, velocity potential, and stream function, which are obtained either by the simulation or observations. 
(a) JJ Difference (CAl200 minus CAl850)

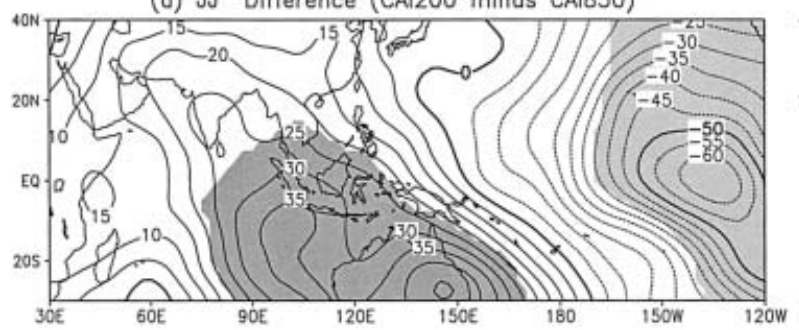

(b) AS Difference (CAl200 minus CAl850)

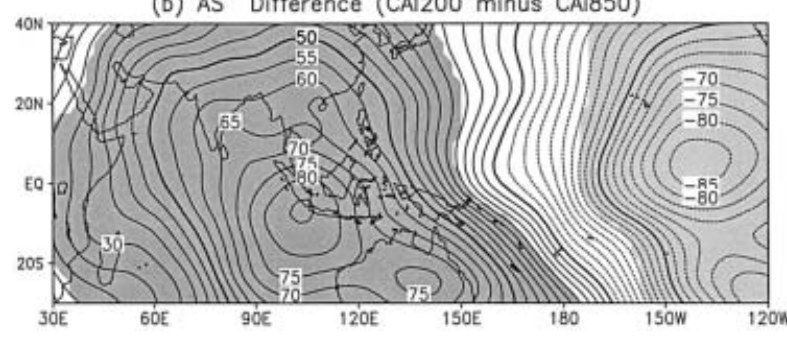

(c) ON Difference (CAI200 minus CAI850)

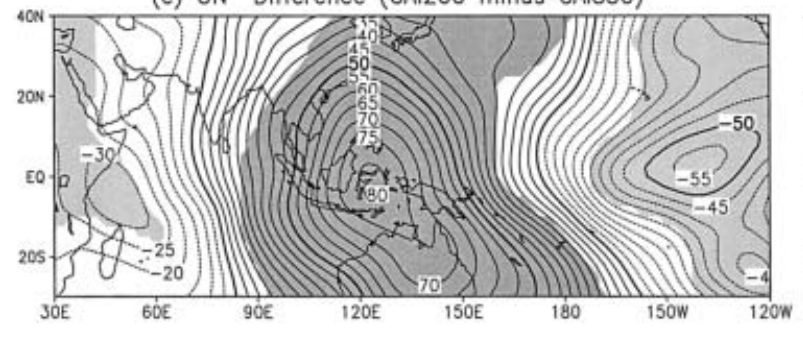

(d) DJ Difference (CAI200 minus CA1850)

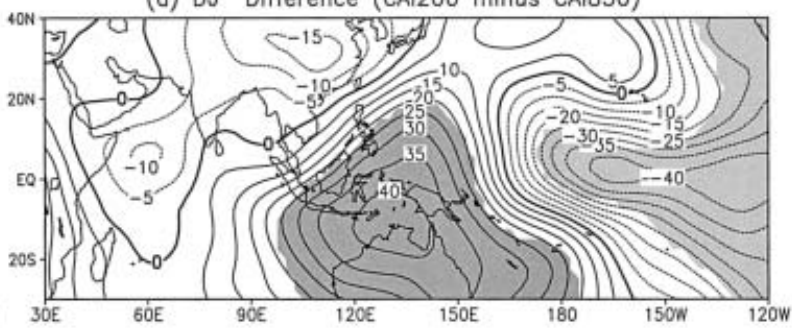

(e) FM Difference (CAI200 minus CAI850)

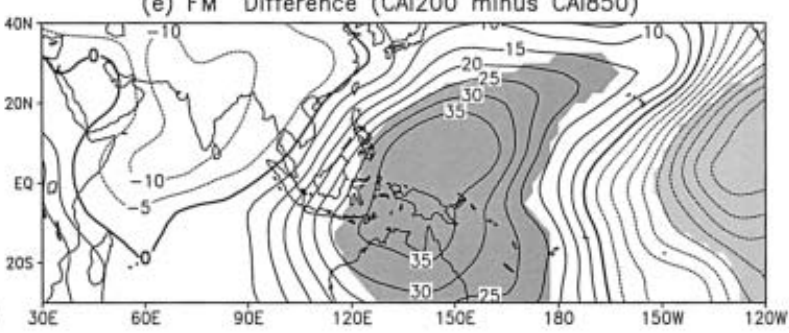

(f) AM Difference (CAI200 minus CAI850)

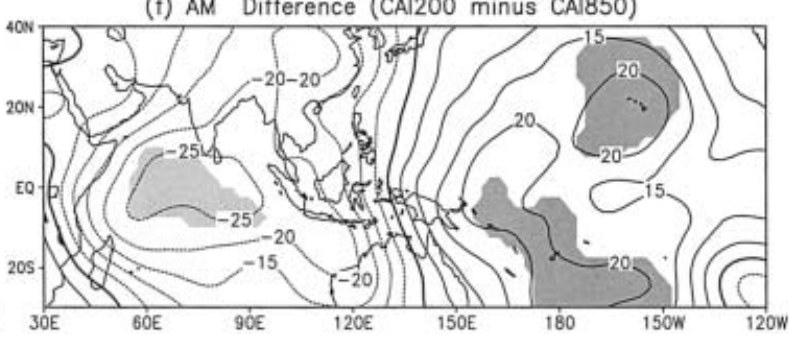

Fig. 2. Composite differences in VPD (200-hPa minus 850-hPa) between strong monsoon/cold event and weak monsoon/warm event categories (former minus latter) during the period from the 1960s to the mid-1970s for (a) June-July, (b) August-September, (c) October-November, (d) DecemberJanuary, (e) February-March, and (f) April-May. Contour interval is $5 \times 10^{5} \mathrm{~m}^{2} \mathrm{~s}^{-1}$. Shading indicates the regions where values are different from zero at the $5 \%$ level of statistical significance using a Student's $t$-test.

\section{Results}

\subsection{Composite anomalies of the atmosphere}

To understand ascending and descending branches of the large-scale east-west circulation in the tropics, we use the velocity potential difference (VPD) between $200-\mathrm{hPa}$ and 850 $\mathrm{hPa}$. The usefulness of VPD is confirmed by $\mathrm{Li}$ and Zhang (2002). Figure 2 shows the VPD composite differences between strong monsoon/ cold event and weak monsoon/warm event categories (former minus latter) during the period from the 1960s to mid-1970s for June-July (year0), August-September (year0), OctoberNovember (year0), December-January (year0/ +1 ), February-March (year+1), and April-May (year +1$)$. The "year0" and "year +1 " denotes the reference year and the subsequent year, respectively. Note that to save space, composite anomaly maps for respective categories are not presented. It is well known that the large-scale east-west circulation has an ascending branch over the Asian-Australian monsoon region and descending branches to the west and east (e.g., Webster et al. 1998; Meehl and Arblaster 2002). In terms of climatology, the center of divergence is located over the Philippine Sea in early summer and migrates southeastward until the subsequent winter (figure not shown). In early summer, positive and negative anomalies are indicated over the tropical Indian and Pacific oceans, respectively, implying the pres- 
ence of an anomalous east-west circulation between those oceans. The Indian subcontinent is covered by statistically significant anomalies in late summer rather than in early summer, which is consistent with Nino-3 SST (JJA) being correlated with MTG (AS) $(r=-0.90)$ more than MTG (JJ) $(r=-0.62)$ during the 15-yr period 1962-1976 (Table 1). The positive anomalies over the tropical Indian Ocean, the amplitude of which is the largest $\left(85 \times 10^{5} \mathrm{~m}^{2} \mathrm{~s}^{-1}\right)$ in late summer, migrate eastward to the maritime continent from late summer to winter, but the negative anomalies over the central and eastern Pacific are almost stationary until midwinter. Furthermore, another negative anomaly is generated in the vicinity of Madagascar in fall. These indicate that a tropical east-west circulation system over the Indian and Pacific oceans changes from a single-cell regime in summer to a double-cell regime in autumn in terms of interannual variability. Here the term "cell" is used as an anomalous east-west circulation with an ascending branch and a descending branch in the tropics. Such a regime shift is intimately related to tropical SST anomalies, as will be discussed later. Of course, the change in the anomalous east-west circulation also occurs to the west of $30^{\circ} \mathrm{E}$ and to the east of $120^{\circ} \mathrm{W}$, linked with that over the tropical Indian and Pacific oceans, but in this study we focus specifically on the behavior of the anomalous east-west circulation over the two oceans. So in that sense, we note that "single-cell" and "double-cell" regimes are valid solely for the sector analyzed in this study.

As seen in the December-February (DJ) panel, positive anomalies over the maritime continent decay, as compared with those in fall, and abruptly shift eastward into the central Pacific between February-March (FM) and April-May (AM). After the phase transition, the Indian Ocean is covered by negative anomalies, which is contrasted with JJ pattern. That is, the anomalous Walker circulation system over the Indian and Pacific oceans is back to a single-cell regime, with the exception of an opposite sign, prior to the subsequent summer monsoon.

In Fig. 3, the composite differences in 850$\mathrm{hPa}$ stream function anomalies are shown in the same way as Fig. 2. A north-south symmetric structure about the equator is observed over the Indian Ocean from late summer to fall, and remarkable cyclonic circulation anomalies expand from the Arabian Sea to the Indian subcontinent and the Bay of Bengal, indicating a signature of strong monsoon. This north-south pair moves eastward into the western Pacific and the Australian continent from autumn to late winter. By contrast, anticyclonic circulation anomalies over the tropical Pacific tend to be stationary till late winter. Nearly concurrent with a rapid eastward shift of the twin cyclonic circulation anomalies between FM and AM, the Pacific anticyclonic circulation anomalies disappear. These anomalous features are consistent with the $200-\mathrm{hPa}$ velocity potential anomaly patterns as seen in Fig. 2. We stress here that the anomalous Walker circulation system over the Indian and Pacific oceans relevant to monsoon activity exhibits a noticeable doublecell structure in October-November (ON) and DJ, different from a single-cell structure seen in other months.

Figure 4 shows the NCEP rainfall and 850$\mathrm{hPa}$ wind composite differences between strong monsoon/cold event and weak monsoon/warm event categories. A low-level cyclonic circulation anomaly is observed over the Arabian Sea in late summer, dynamically linked with a strong monsoon rainfall over India. This anomalous circulation is similar to the leading dualvariate empirical orthogonal function (EOF) mode of $850-\mathrm{hPa}$ winds in the South Asian monsoon region extracted by Wang et al. (2001). Another anomalous cyclonic circulation appears over the western South Indian Ocean. Along the equator, westerly anomalies are indicated over the Indian Ocean and anomalous easterlies prevail over the tropical Pacific, exhibiting the intensification of tropical eastwest circulation. It is also characteristic that a north-south pair of positive rainfall anomalies is found over the tropical Indian Ocean. The above equatorial symmetric structures over the Indian Ocean become evident from late summer to fall when the cold ENSO event develops. In the ON and DJ panels, positive rainfall anomalies over the eastern tropical South Indian Ocean are zonally elongated and also cover Java, Timor Sea and Arafra Sea. This feature is consistent with an observational study by Hamada et al. (2002), who showed an influential role of ENSO in the austral mon- 
(a) JJ PSI850

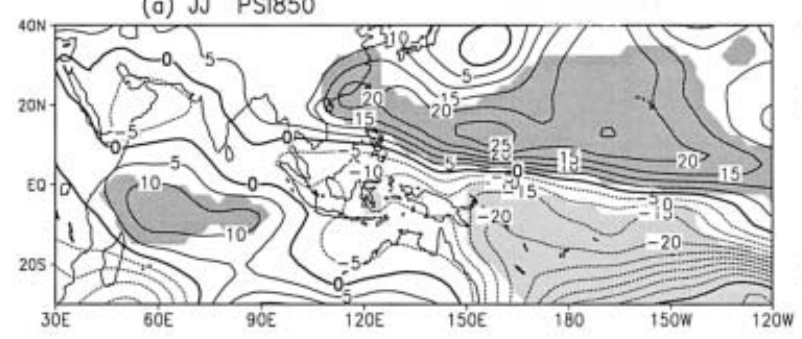

(b) AS PS1850

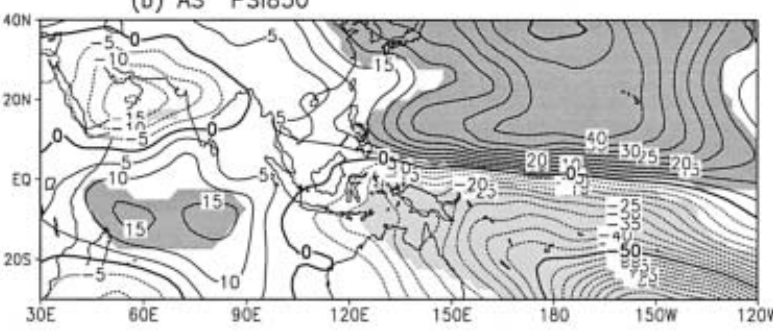

(c) ON PSI850



(d) DJ PSI850

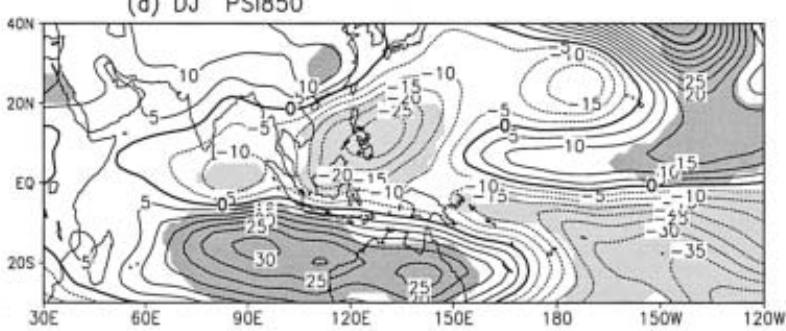

(e) FM PSI850

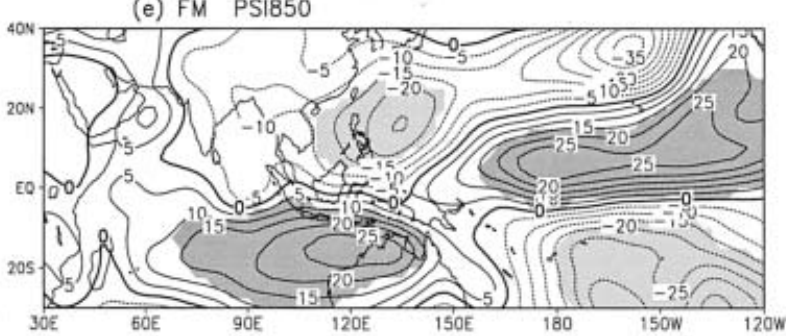

(f) AM PSI850

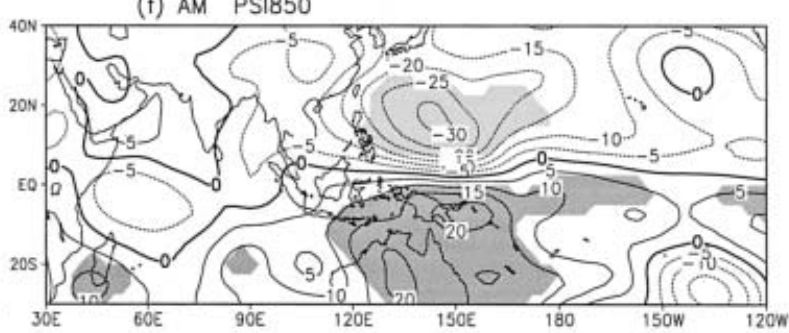

Fig. 3. As in Fig. 2 but for $850-\mathrm{hPa}$ stream function. Contour interval is $5 \times 10^{5} \mathrm{~m}^{2} \mathrm{~s}^{-1}$.

soon onset of Java, using in situ rain gauge data (see also Appendix C).

Corresponding to the establishment of a double-cell regime in the anomalous east-west circulation system overlying the tropical Indian and Pacific oceans (Fig. 2c), twin cyclonic circulation anomalies on each side of the equator migrate eastward to the eastern Indian Ocean, together with enhanced rainfall areas, whereas the western part of the tropical Indian Ocean is covered by negative rainfall anomalies. As the enhanced rainfall shifts from the Indian Ocean to the western Pacific, shown in the DJ and FM panels, low-level westerly anomalies intrude into the warm pool region of the western Pacific and, conversely, easterly anomalies over the tropical Pacific retreat eastward. After FM, the positive rainfall anomalies over the western tropical Pacific are rapidly dissipated, while new positive anomalies appear over the equa- torial Pacific east of $150^{\circ} \mathrm{W}$ accompanied by anomalous westerlies.

As previously stated, the correlation between MTG (AS) and AIR is very high during the period 1962-1976 despite the fact that both indices do not necessarily coincide with each other. One possible reason is that the monsoon interannual variability depends largely on circulation anomalies at the late stage of the monsoon season during that period. Another reason is that AIR may reflect local rainfall amount, especially over the central and northwestern parts of India because, in the AS panel, positive rainfall anomalies over Indian are localized in its central and northwestern parts.

\subsection{Composite anomalies of the ocean}

Figure 5 shows the composite features of observed SST anomalies linked with the ENSOmonsoon relationship during the period from 
(a) JJ RAIN \& $850[U, V]$

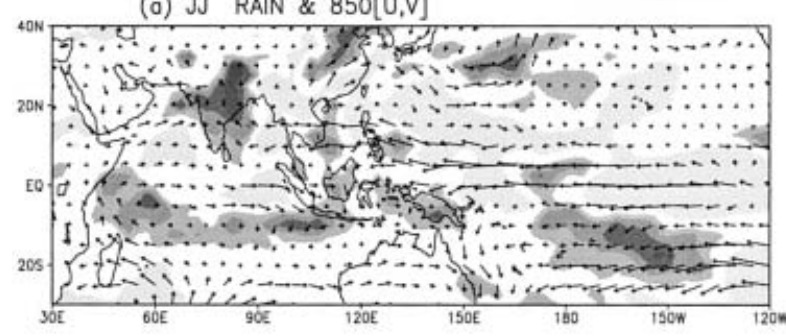

(b) AS RAIN \& 850[U,V]

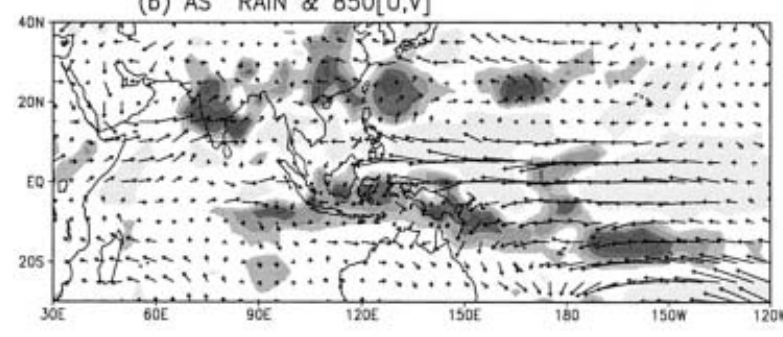

(c) ON RAIN \& $850[U, V]$

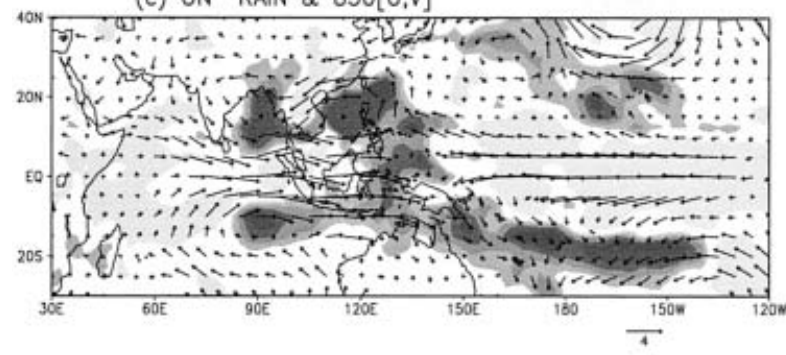

(d) DJ RAIN \& $850[\mathrm{U}, \mathrm{V}]$

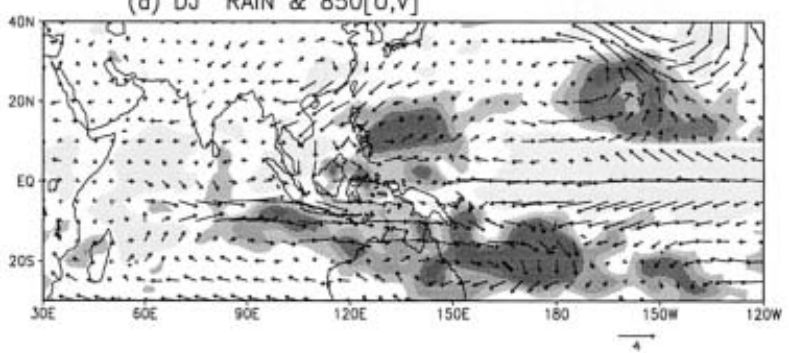

(e) FM RAIN \& $850[\mathrm{U}, \mathrm{V}]$

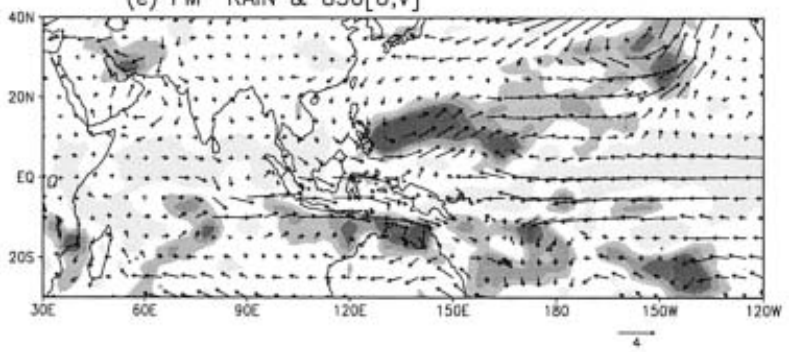

(f) AM RAIN \& $850[\mathrm{U}, \mathrm{V}]$

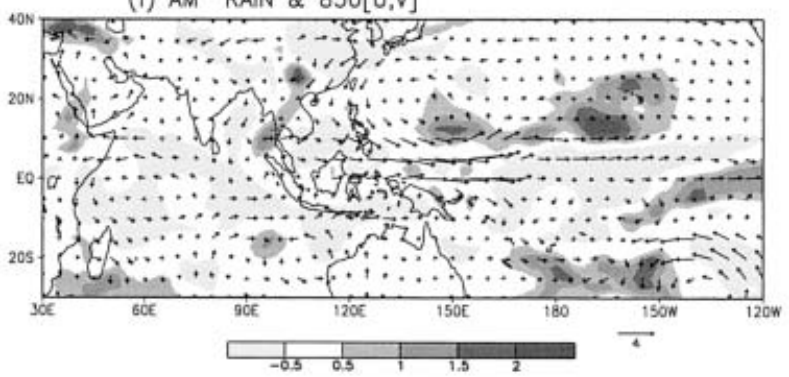

Fig. 4. Composite differences in NCEP rainfall and 850-hPa wind anomalies between strong monsoon/cold event and weak monsoon/warm event categories for (a) June-July, (b) August-September, (c) October-November, (d) December-January, (e) February-March, and (f) April-May. Heavy and light shadings denote significant positive and negative rainfall anomalies, respectively. Reference arrow is $4 \mathrm{~m} \mathrm{~s}^{-1}$.

the 1960s to mid-1970s. Also exhibited are 850$\mathrm{hPa}$ wind anomalies. When the cold event of ENSO develops, negative SST anomalies are induced over the western tropical Indian Ocean in late summer. In particular, negative SST anomalies over the Arabian Sea are related to strong monsoon activity (e.g., Ju and Slingo 1995; Li and Yanai 1996). As an east-west circulation cell is established over the tropical Indian Ocean from late summer to fall, negative anomalies expand into the entire region of the tropical Indian Ocean and South China Sea, accompanied by low-level anomalous westerlies. Such appreciable SST cooling suppresses tropical convection over those regions and may contribute to localization of intense convection over the maritime continent and the western Pacific as a result. As already shown in Fig. 2, the phase transition of the tropical east-west circulation system appears between FM and AM. Corresponding to this phase transition, the sign of SST anomalies east of the Philippines changes from positive to negative, while negative SST anomalies over the central equatorial Pacific relevant to the cold ENSO event become weak rapidly. Appearance of distinctive westerly anomalies over the warm pool region of the western Pacific is most likely to be a trigger of the turnabout of ENSO in the sense of generating oceanic Kelvin waves.

Another indication in Fig. 5 is persistence of basin-wide negative SST anomalies over the 
(a) JJ OBS SST \& $850[\mathrm{U}, \mathrm{V}]$

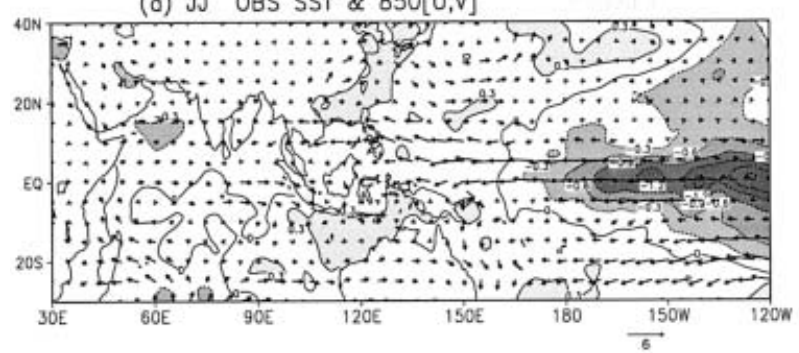

(b) AS OBS SST \& $850[U, V]$

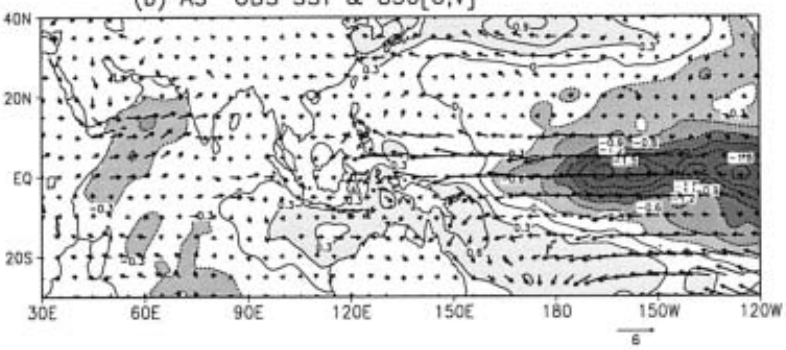

(c) ON OBS SST \& 850[U,V]

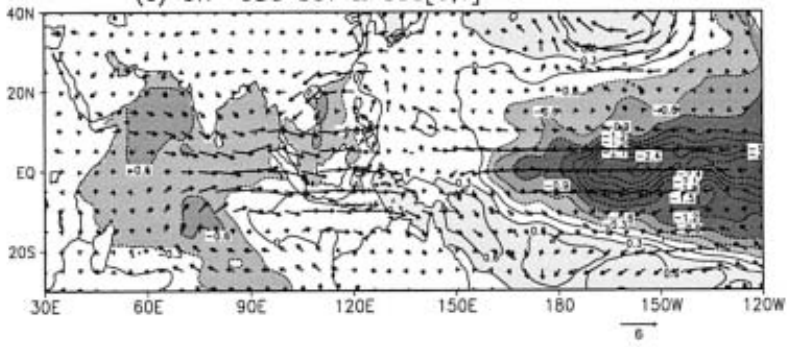

(d) DJ OBS SST \& $850[\mathrm{U}, \mathrm{V}]$

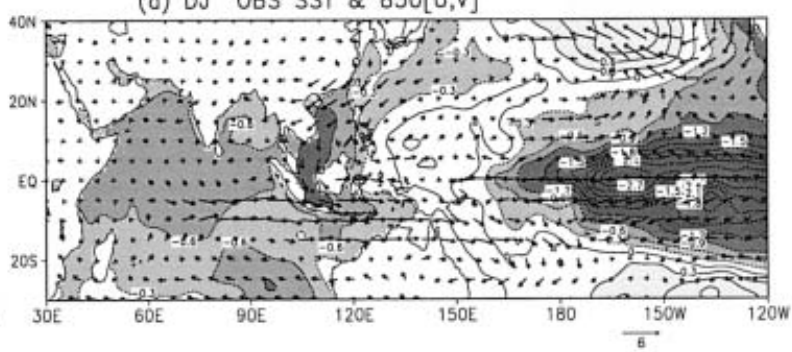

(e) FM OBS SST \& $850[\mathrm{U}, \mathrm{V}]$

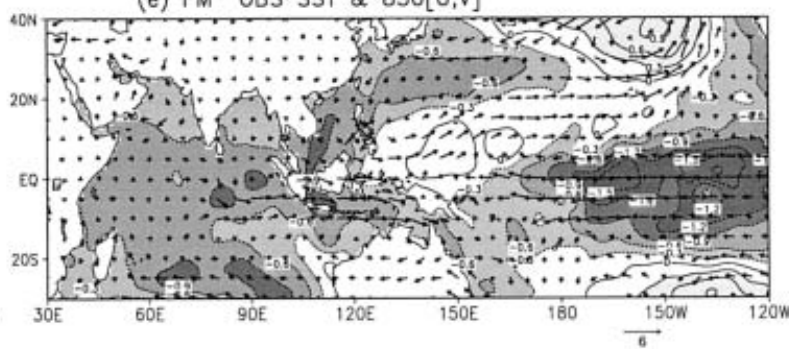

(f) AM OBS SST \& $850[\mathrm{U}, \mathrm{V}]$

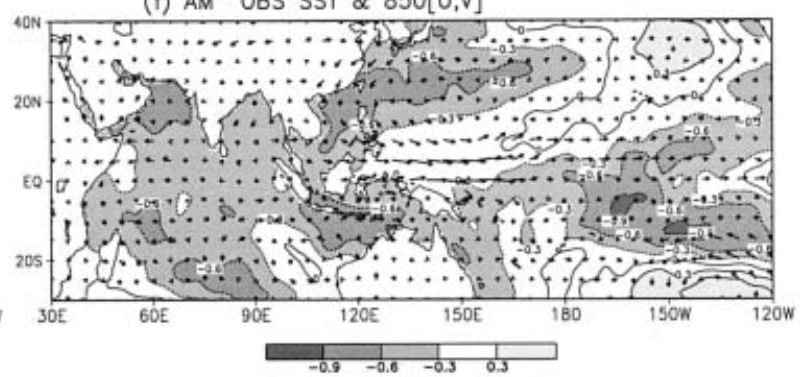

Fig. 5. Composite differences in observed SST anomalies between strong monsoon/cold event and weak monsoon/warm event categories (former minus latter) for (a) June-July, (b) August-September, (c) October-November, (d) December-January, (e) February-March, and (f) April-May. Contour interval is $0.3^{\circ} \mathrm{C}$. Also shown are the composite anomalies of 850 -hPa wind.

tropical Indian Ocean from late summer to the following spring. Moreover, its spatial extension reaches the subtropical regions of the Indian Ocean, as contrasted with the central and eastern Pacific characterized by remarkable anomalies near the equator. This difference may depend on the relative role of equatorial oceanic waves in generating those SST anomalies, as will be discussed later. Although we can see an ascending (descending) branch over the Pacific (Indian Ocean) region in Fig. 2f, which is viewed as a single-cell regime in the anomalous east-west circulation, it is inferred that the persistent basin-wide negative SST anomalies over the tropical Indian Ocean play a significant role in generating this single-cell regime.
Figure 6 demonstrates the composite differences in model-simulated SST and wind stress vector anomalies between strong monsoon/cold event and weak monsoon/warm event categories before the late $1970 \mathrm{~s}$. It is well simulated that negative SST anomalies are initiated over the Arabian Sea in early summer and then expand into the whole region of the tropical Indian Ocean. However, two major discrepancies can be seen between the observation and simulation. One is that simulated warm anomalies over the western tropical Pacific east of the Philippines are too strong. Although, of course, we cannot disregard the difference, a decrease in SST over that region from DJ to AM is similar to that observed. The SST decrease attenu- 
(a) JJ Model SST \& [Toux,Tauy]

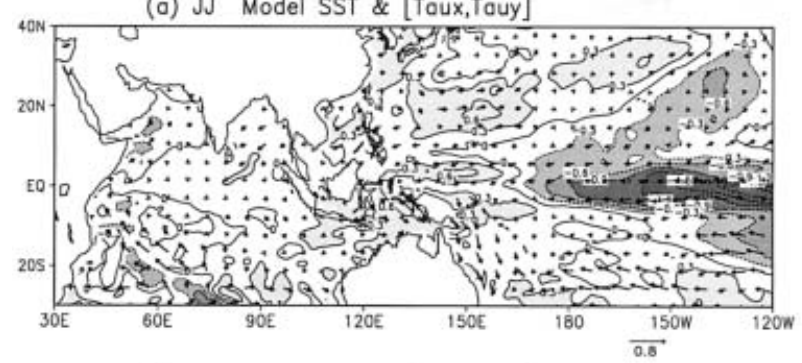

(b) AS Model SST \& [Taux, Tauy]

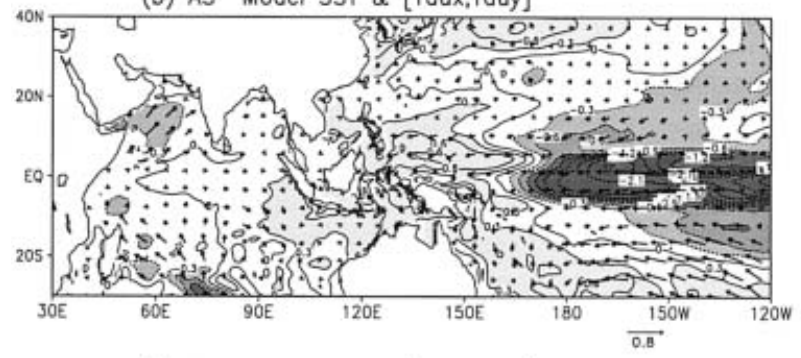

(c) ON Model SST \& [Toux,Tauy]

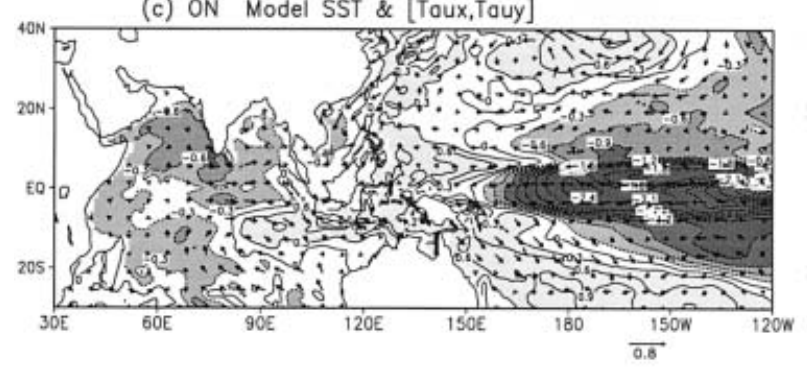

(d) DJ Model SST \& [Taux, Tauy]

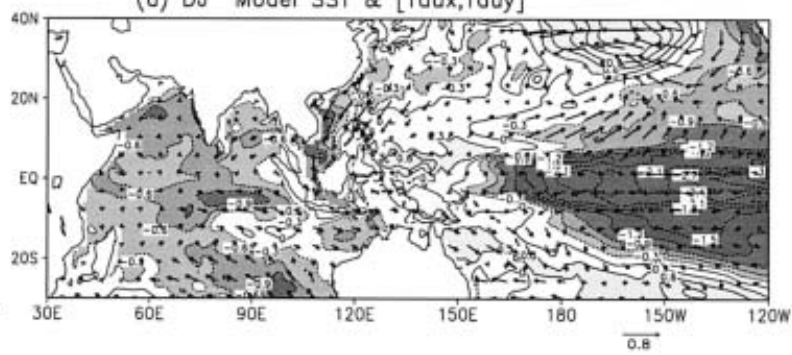

(e) FM Model SST \& [Taux, Tauy]

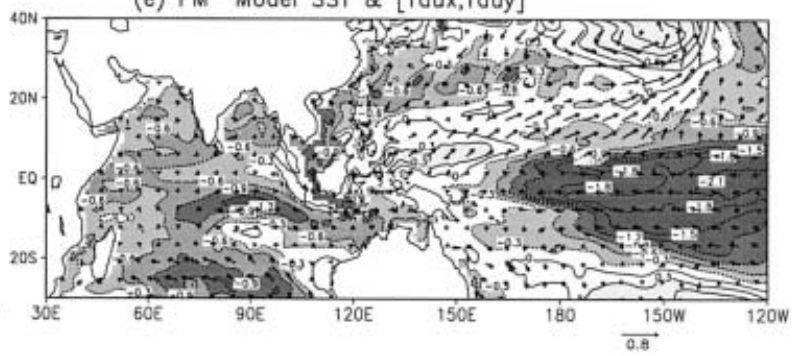

(f) AM Model SST \& [Toux, Touy]

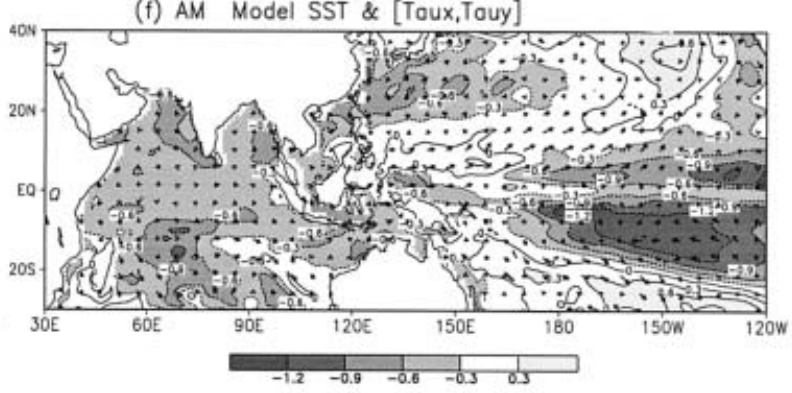

Fig. 6. As in Fig. 5 but for model-simulated SST. Contour interval is $0.3^{\circ} \mathrm{C}$. Also shown are the composite anomalies of wind stress vector in units of dyn $\mathrm{cm}^{-2}$.

ates the overlying tropical convection and contributes to the disruption of the double-cell regime with an ascending branch over the maritime continent and two descending branches over the western Indian and central Pacific oceans. The other is that, in the AM panel, relatively warm anomalies over the central and eastern tropical Pacific, compared to its surrounding regions, are simulated along the equator. This indicates a signature of downwelling equatorial Kelvin waves propagating eastward along the equator, described later. The warming of SST over the central and eastern Pacific due to such a downwelling process also plays an influential role in disrupting the double-cell regime.

To understand to what degree tropical SSTs are associated with underlying subsurface ocean temperatures, we present, in Fig. 7, the simultaneous correlation between modelsimulated SST and subsurface temperature anomalies at each depth along the equator during the 15-yr period 1962/63-1976/77 for JJ, AS, ON, DJ, FM, and AM. Note that a correlation coefficient of 0.514 is the $5 \%$ statistical significance level. Also exhibited are climatological mean temperatures. An immediate indication is the different characteristics between the equatorial Indian Ocean and the central and eastern equatorial Pacific. In the equatorial Indian Ocean, very significant correlation areas tend to be trapped within the nearsurface layer above a depth of about $30 \mathrm{~m}$, although high correlations can be seen at $60-$ $90 \mathrm{~m}$ depth in the western Indian Ocean. Similar features also can be seen in off-equatorial 
(a) JJ SST vs Temp. ot EQ

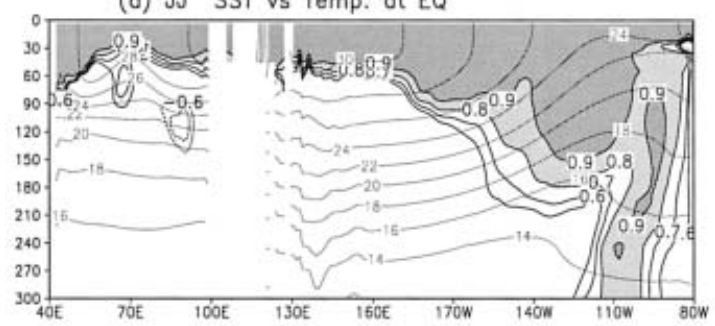

(b) AS SST vs Temp, ot EQ

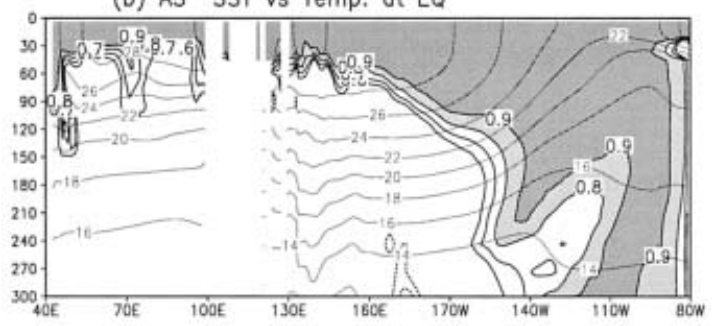

(c) ON SST vs Temp. at EQ

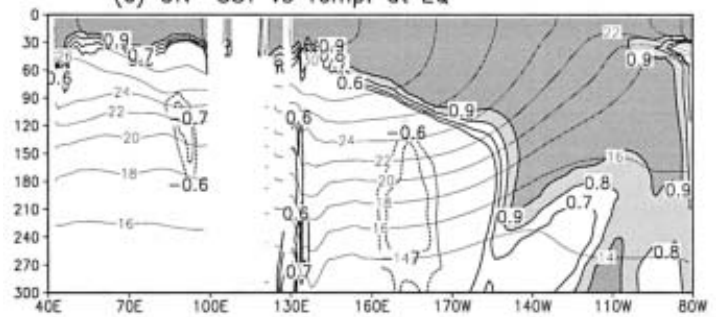

(d) DJ SST vs Temp. at EQ

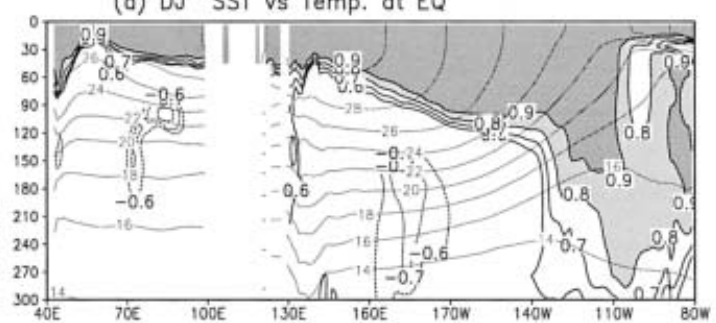

(e) FM SST vs Temp, ot EQ

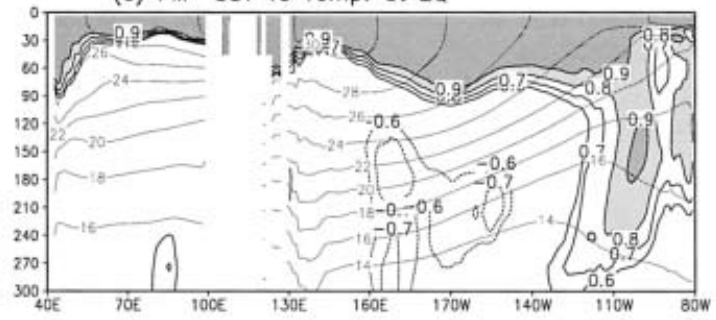

(f) AM SST vs Temp, at EQ

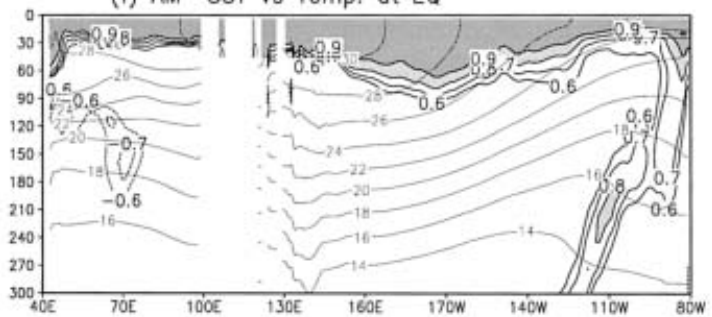

Fig. 7. Vertical depth-longitude sections of the simultaneous correlation between model-simulated SST and subsurface temperature anomalies at each depth along the equator during the 15-yr period 1962/63-1976/77 for (a) June-July, (b) August-September, (c) October-November, (d) December-January, (e) February-March, and (f) April-May. The correlation fully satisfying the 5\% level of statistical significance is only plotted. Shading denotes regions of greater than 0.8. Climatological mean subsurface temperautres are also shown by thin lines.

regions (figure not shown). In the central and eastern equatorial Pacific, in contrast, high correlation areas reach the subsurface layer below a depth of about $100 \mathrm{~m}$. This feature is most evident from late summer to early winter, but it is not clear from late winter to spring. Especially in the eastern equatorial Pacific in AM, such high correlation layers are very shallow, comparable to those in the equatorial Indian Ocean.

These regional and seasonal differences may be intimately related to the behavior of both the depth of thermocline and the equatorial upwelling. Because the depth of the thermocline in the equatorial upwelling region of the eastern Pacific is generally very shallow, its variations significantly affect those in SST. In addition, the thermocline depth is shallower from late summer to early winter and is deeper from late winter to spring. As already seen in Fig. $7 f$, the correlations are high only in the near-surface layer in spring when the thermocline depth is deepest. Compared to the eastern equatorial Pacific, the depth of thermocline is significantly deep in the eastern Indian Ocean and the western Pacific where the equatorial upwelling is not very dominant, which suggests that its variations cannot easily induce the overlying SST anomalies. It is considered that equatorial oceanic waves largely affect the interannual variations in the thermocline depth. Thus, the behavior of the equatorial waves is 
(a) JJ Temp. at EQ

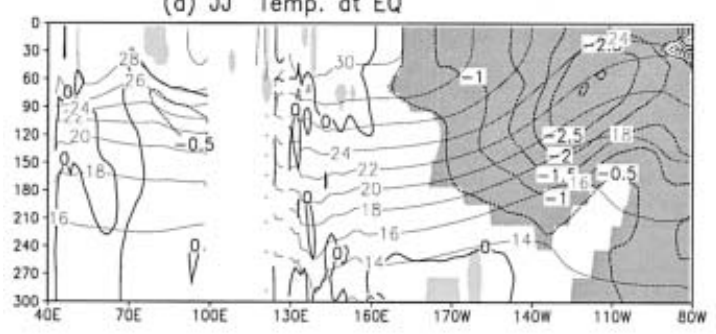

(b) AS Temp. at EQ

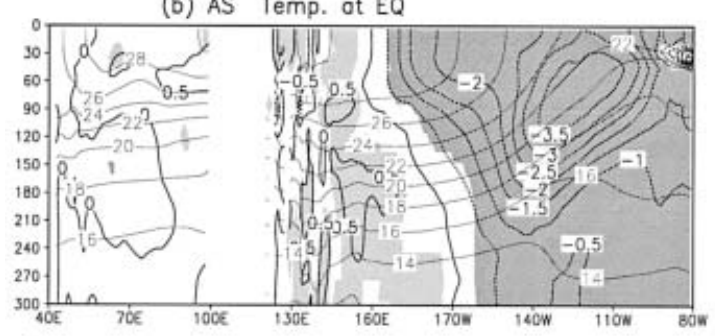

(c) ON Temp. at EQ

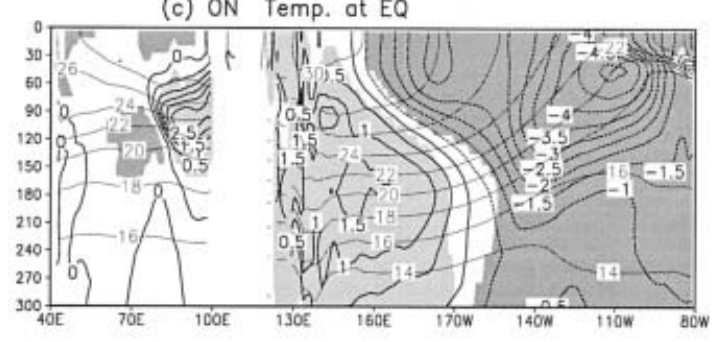

(d) DJ Temp. at EQ

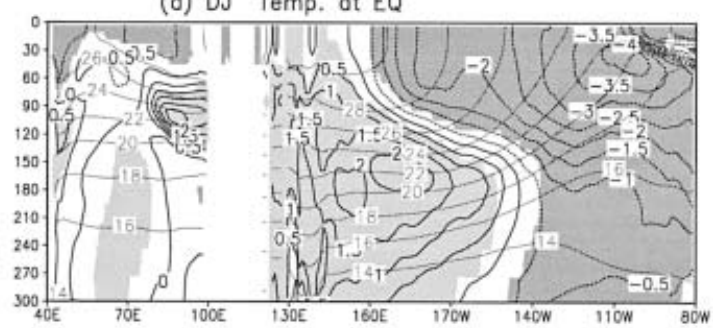

(e) FM Temp. at EQ

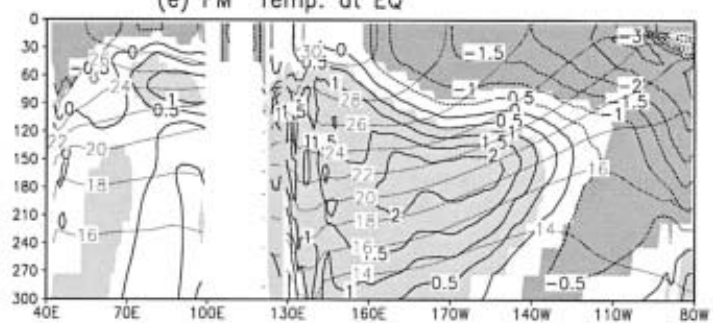

(f) AM Temp. at EQ

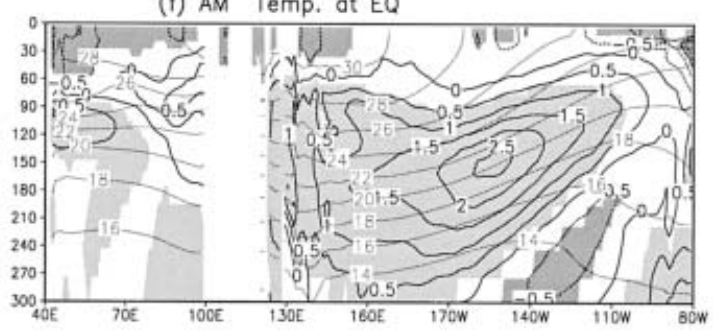

Fig. 8. Vertical depth-longitude sections of the composite differences in simulated subsurface temperature anomalies between strong monsoon/cold event and weak monsoon/warm event categories along the equator for (a) June-July, (b) August-September, (c) October-November, (d) DecemberJanuary, (e) February-March, and (f) April-May. Contour interval is $0.5^{\circ} \mathrm{C}$. Shading indicates the regions where values are different from zero at the $5 \%$ level of statistical significance using a Student's $t$-test. Climatological mean temperautres are also shown by thin lines.

well correlated with SST anomalies in the eastern Pacific, but is probably less linked with those in the eastern Indian Ocean and the western Pacific. Xie et al. (2002) pointed out the importance of a westward-propagating downwelling Rossby wave to the generation and propagation of positive SST anomaly over the tropical South Indian Ocean $\left(8^{\circ}-12^{\circ} \mathrm{S}\right)$. In the specific regions of the tropical Indian Ocean, the ocean dynamics may be more important than the other factors, such as surface heat flux.

To examine possible roles of equatorial ocean dynamics in the phase transition of the anomalous Walker circulation system over the Indian and Pacific oceans, the depth-longitude cross sections of subsurface ocean temperature composites along the equator are demonstrated in Fig. 8. The peak cold phase of ENSO is around October or November. In both warm pool regions of the eastern Indian and western Pacific oceans, accumulation of warm water is simulated (Fig. 8c), but the center of the corresponding anomalies is located at a depth of about $100 \mathrm{~m}$ in the eastern Indian Ocean and of about $180 \mathrm{~m}$ in the western Pacific because of the difference in thermocline depth. After the peak phase, warm anomalies in the equatorial Pacific migrate eastward and reach the nearsurface layer of the eastern Pacific in AM, implying that downwelling Kelvin waves propagate eastward along the equator, and conse- 
quently, a warm event of ENSO begins. Since the thermocline depth in the equatorial upwelling region of the eastern Pacific is shallower from late summer to early winter, it seems that the eastward-propagating downwelling Kelvin waves can easily increase SSTs over that region. Although the excitation of equatorial Kelvin waves may be related to the reflection of westward-propagating Rossby waves in the western tropical Pacific (e.g., Schopf and Suarez 1988), the intrusion of lowlevel westerly anomalies into the warm pool region of the western Pacific (see Figs. 4d and 4e) also may favor the excitation of the equatorial Kelvin waves (e.g., Masumoto and Yamagata 1991). Zhang and Levitus (1997) postulated that the interannual variability of subsurface ocean thermal anomalies relevant to ENSO represents a slowly evolving coupled ocean-atmosphere mode, rather than free oceanic Kelvin and Rossby wave modes. The eastward migration of subsurface warm anomalies seen in Fig. 8 is considerably slow if the phenomenon is regarded as a signature of internal Kelvin waves. To account for Fig. 8, their coupled mode might be more appropriate than the internal modes.

In the eastern Indian Ocean, by contrast, warm anomalies near the thermocline become dissipated from DJ to AM. In Fig. 9, which shows subsurface temperature composites at a depth of $105 \mathrm{~m}$, approximately equivalent to the thermocline depth in the eastern Indian Ocean, it is found that a north-south pair of positive anomalies migrate westward in the eastern Indian Ocean from late winter to (a) JJ Model T(105m depth)

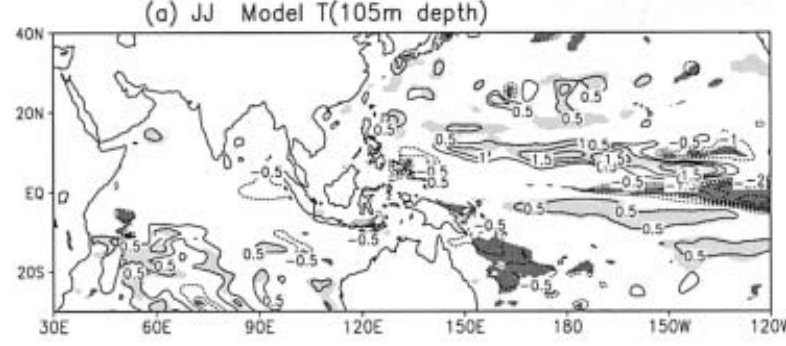

(b) AS Model T(105m depth)

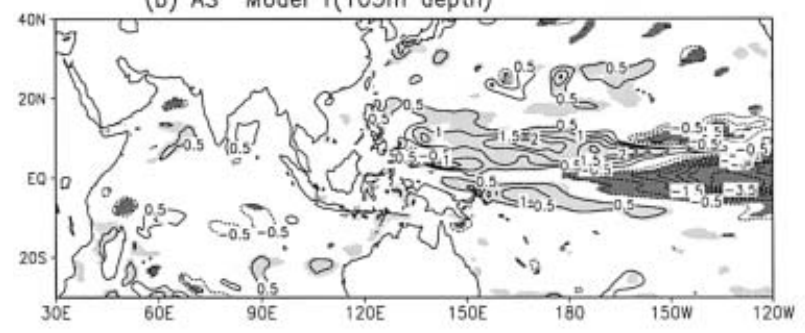

(c) ON Model T(105m depth)

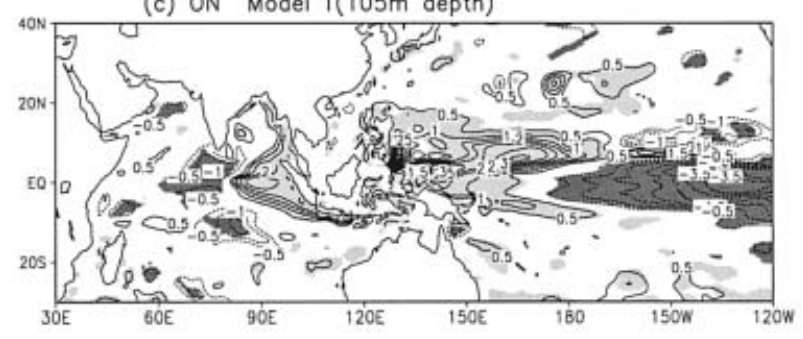

(d) DJ Model T(105m depth)

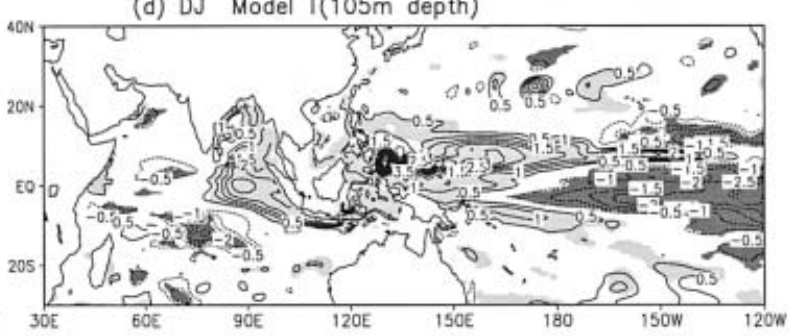

(e) FM Model T(105m depth)

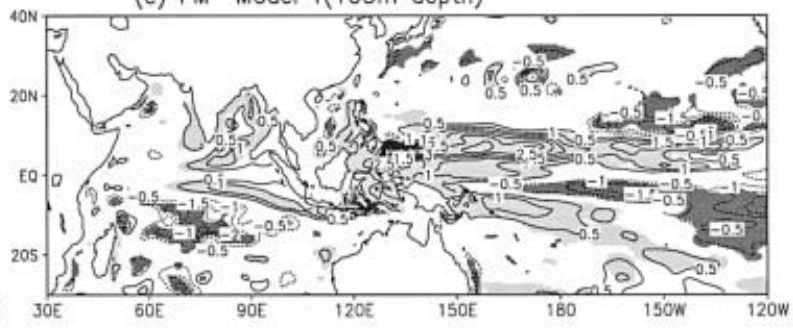

(f) AM Model T(105m depth)

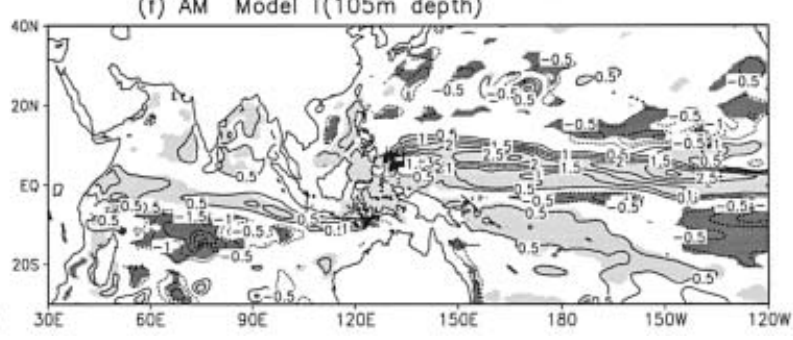

Fig. 9. Composite differences in simulated subsurface temperature anomalies at a depth of $105 \mathrm{~m}$ between strong monsoon/cold event and weak monsoon/warm event categories for (a) June-July, (b) August-September, (c) October-November, (d) December-January, (e) February-March, and (f) April-May. Contour interval is $0.5^{\circ} \mathrm{C}$. Shading indicates the regions where values are different from zero at the $5 \%$ level of statistical significance using a Student's $t$-test. 
spring. This can be identified with the westward propagation of a pair of downwelling Rossby waves in the equatorial Indian Ocean. The figure also shows that positive anomalies in the eastern equatorial Indian Ocean extend northward along the west coasts of Sumatra and Indochina peninsula and intrude into the Bay of Bengal, indicating a dominance of coastal Kelvin waves. Despite the dominance of equatorial waves in the Indian Ocean, however, basin-wide negative SST anomalies over the tropical Indian Ocean are sustained from DJ to AM, as indicated in Figs. 5 and 6. This feature is significantly distinguished from the central and eastern equatorial Pacific where equatorial oceanic waves play a vital role in generating SST anomalies.

Since the change in surface heat flux exchange is thought to contribute to the formation of the basin-wide negative SST anomalies from late summer to the following winter, we present, in Fig. 10, the surface latent heat flux and wind stress composite differences for AS and ON. Note that positive latent heat flux anomalies imply increased evaporation from the ocean surface. In late summer, positive surface latent heat flux anomalies are found over the northern and western parts of the tropical Indian Ocean, while negative flux anomalies are seen over the eastern South Indian Ocean southwest of Sumatra. The positive latent heat flux anomalies further expand into the whole region of the Indian Ocean in fall, except the area southwest of Sumatra. The Philippine Sea is also characterized by positive flux anomalies. In particular, outstanding positive anomaly areas south of Sri Lanka and west of Australia are accompanied by enhanced wind stress. Conversely, a negative anomaly area southwest of Sumatra is accompanied by weakened wind stress. This suggests that surface evaporation depends strongly on wind speed. Because negative SST anomalies are induced over the whole region of the tropical Indian Ocean in fall, as seen in Fig. 5c, we anticipate that increased evaporation due to enhanced wind speed contributes substantially to the basinwide SST cooling over the tropical Indian Ocean.

The importance of latent heat flux as a cause of SST changes over tropical oceans outside of the equatorial waveguide has been pointed out

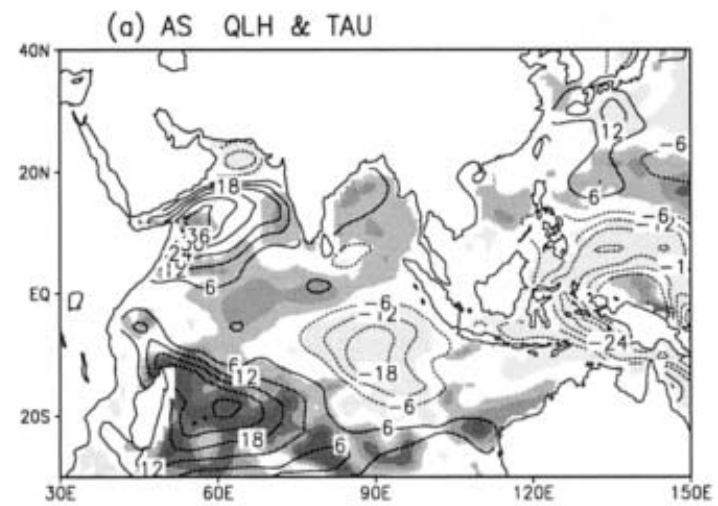

(b) ON QLH \& TAU

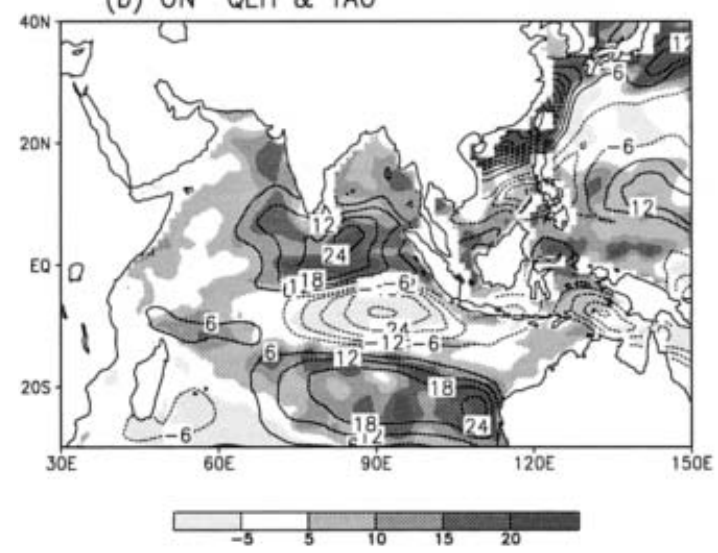

Fig. 10. Composite differences in surface latent heat flux anomalies between strong monsoon/cold event and weak monsoon/warm event categories for (a) August-September, and (b) OctoberNovember. Unit is $\mathrm{W} \mathrm{m} \mathrm{m}^{-2}$. Heavy and light shadings denote significant positive and negative latent heat flux anomalies, respectively. Also shown are the composite anomalies of scalar wind stress. Contour interval is $6 \times$ $10^{-2}$ dyn $\mathrm{cm}^{-2}$.

in recent studies (e.g., Yu and Rienecker 1999; Lau and Nath 2000, 2003). According to Shaji et al. (2003), in particular, the time tendency of the near-surface heat budget in the Bay of Bengal depends mainly on the net surface heat flux. Baquero-Bernal et al. (2002) also found that, in boreal fall, the ENSO-related SST response of the tropical Indian Ocean exhibits a dipole-like pattern, which is very similar to Figs. 5c and 6c, and postulated that this dipole- 
like variability is forced by surface heat flux anomalies. As for the warm pool region of the western Pacific, Kawamura et al. (2001b) made a heat budget analysis on a daily basis with respect to the upper $50 \mathrm{~m}$ and showed that surface heat flux, especially latent heat flux, is mainly responsible for the time-tendency of heat content and vertical advection plays a secondary role in originating it.

The negative latent heat flux anomaly area southwest of Sumatra also corresponds to a relatively warm SST anomaly area. Furthermore, the cooling of SST over the Arabian Sea from early summer to fall may be attributed to vertical mixing as well as surface latent heat flux because, in AS panel of Fig. 10, we see enhanced wind stress over the Arabian Sea where the ocean mixed layer is considerably thin. It is inferred that the evaporative cooling in the surface layer reinforces vertical mixing, leading to further SST cooling.

Downwelling Rossby waves propagating westward in the tropical Indian Ocean are simulated from DJ to AM (Fig. 9d-f). Several recent studies emphasize an influential role of ocean dynamics in generating SST anomalies over the tropical Indian Ocean (e.g., Saji et al. 1999; Webster et al. 1999; Iizuka et al. 2000; Rao et al. 2002; Xie et al. 2002). Of course, we agree with their argument on such dynamics in the tropical Indian Ocean. However, the basinwide negative SST anomalies over the tropical Indian Ocean are sustained over that period despite the dominance of the Rossby waves, as previously stated. Thus, it seems that, in this case, the role of the equatorial waves in inducing SST anomalies over the tropical Indian Ocean is not necessarily significant, compared to that of surface evaporation and vertical mixing. This may be because the thermocline of the western tropical Indian Ocean is generally deeper than that of the eastern equatorial $\mathrm{Pa}$ cific where SST anomalies are directly affected by the dynamic response of the ocean to wind stress forcing, and because equatorial upwelling in the Indian Ocean is not prominent compared to that in the equatorial Pacific.

In terms of equatorially symmetric patterns over the tropical Indian Ocean, such as northsouth dipole cyclonic circulation anomalies and enhanced rainfall anomalies in both hemispheres, prior to the late 1970 s, we term the above atmosphere-ocean circulation anomalies an equatorially symmetric (ES) impact of ENSO on the monsoon activity. The ES impact at the developing phase of ENSO is clear in late summer, as seen in Fig. 1. When the anomalous Walker circulation system over the tropical Indian and Pacific oceans changes from a singlecell regime to a double-cell regime, in accordance with the growth of ENSO, increased moisture supply from the Arabian Sea and intense moisture transport into the Indian subcontinent facilitate above-normal rainfall at the late stage (August-September) of the monsoon season. This implies that the South Asian monsoon activity is influenced by the ES impact. The ES impact on the monsoon at the growth phase of ENSO strongly regulates rainfall amount especially at the late stage of the monsoon season, and consequently, the correlation between MTG (AS) and AIR is very high during the period from the 1960 s to mid1970s.

It is interesting to note that the ES impact may be similar to the first singular value decomposition (SVD) mode obtained by Lau and $\mathrm{Wu}$ (2001). Although their analysis focuses mainly on the boreal summer during the period 1979-98, their SVD1 also has twin low-level circulation anomalies over the Bay of Bengal and the southern Indian Ocean. Since the ES impact operates at the growth phase of ENSO, it also could be observed after the late 1970 s, although it is more dominant before the late 1970 s. On the other hand, Wang et al. (2003) emphasize the equatorially asymmetric feature of circulation anomalies over the tropical Indian Ocean during the summer of the El Nino development. It may sound like their result is not consistent with Lau and Wu (2001) and this study, but we understand that the twin circulation anomalies over the tropical Indian Ocean also can be observed in their extended SVD mode, especially in fall.

\section{Discussion}

\subsection{Transition mechanism of anomalous Walker circulation}

In the previous section, we noted the importance role of the ES impact in the South Asian monsoon interannual variability prior to the late 1970 s. It is still uncertain, however, why the tropical east-west circulation system over 

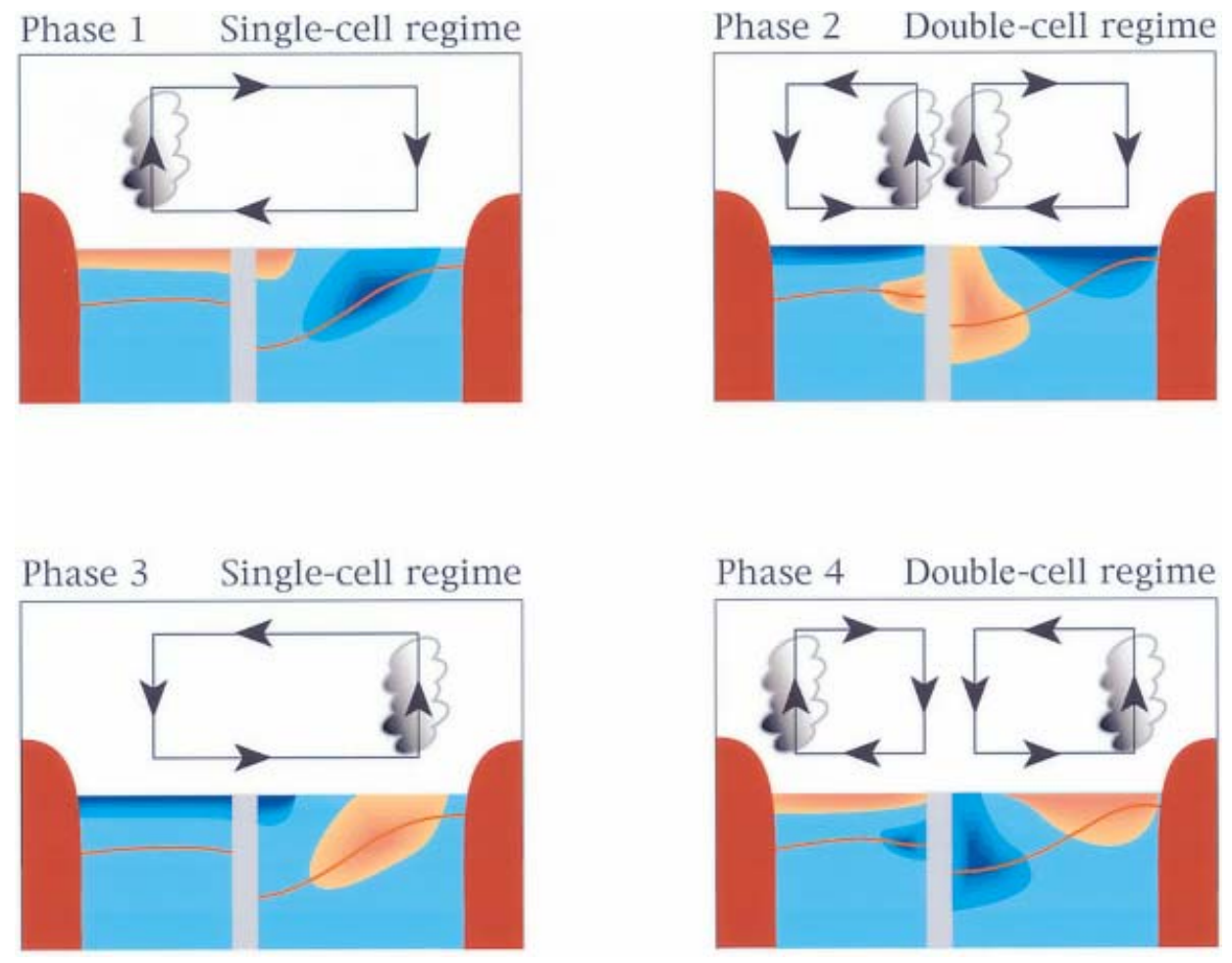

Fig. 11. Schematic diagram representing the transition of anomalous Walker circulation over the tropical Indian and Pacific oceans between single-cell and double-cell regimes, relevant to the ES impact. Arrows denote anomalous Walker circulation cells. Warm and cold temperature anomalies are indicated by orange and blue colors, respectively. A red line at each phase denotes the depth of the climatological mean thermocline.

the Indian and Pacific oceans shifts from one circulation regime to another. Thus, we will discuss a possible mechanism of the regime shift in the anomalous tropical east-west circulation relevant to the ES impact of ENSO, using a schematic diagram.

Figure 11 illustrates the transition of anomalous Walker circulation between single-cell and double-cell regimes from the viewpoint of an atmosphere-ocean coupled system in the tropical Indian and Pacific oceans. Note that anomalous convection in the Indian sector is shown in the sense of tropical mean. First of all, Phase 1 (late spring to early summer) denotes a single-cell regime with an ascending branch over the Indian Ocean and a descending branch over the central and eastern Pacific (see also Fig. 2a), corresponding to the onset phase of a cold event of ENSO. The entire tropical
Indian Ocean is covered by somewhat weak warm SST anomalies, whereas upwelling Kelvin wave-induced cold SST anomalies over the central and eastern Pacific are confined to the vicinity of the equator. This single-cell regime is sustained by the anomalous east-west SST gradient between the two oceans. Due to a dynamic response of enhanced convective heating, low-level westerly anomalies are induced over the western tropical Indian Ocean, bringing about the increase in wind speed near the ocean surface. Increased wind speed causes the SST decrease over the western part of the tropical Indian Ocean through evaporative cooling and vertical mixing. As cold SST anomalies extend eastward into the central and eastern Indian Ocean, enhanced convection area also shifts eastward to the maritime continent. A new east-west circulation cell builds up over 
the tropical Indian Ocean with a strengthened SST gradient between the Indian Ocean and maritime continent (Phase 2). At this phase (fall to winter), the depth of thermocline in the eastern tropical Indian Ocean is deeper than normal due to intensification of westerly anomalies along the equator (see Fig. 8c).

On the other hand, cold SST anomalies over the central and eastern Pacific Ocean develop from Phase 1 to Phase 2. At Phase 2, the depth of thermocline in the western tropical Pacific is deeper than normal as well as that in the eastern tropical Indian Ocean. Another east-west circulation cell over the tropical Pacific is intensified due to a strengthened SST gradient between the western and eastern tropical $\mathrm{Pa}$ cific oceans. A notable feature at this phase is the formation of a double-cell regime with an ascending branch over the maritime continent and two descending branches over the western Indian Ocean and the central and eastern $\mathrm{Pa}-$ cific (Fig. 2c). This double-cell regime corresponds to the mature phase of a cold event of ENSO.

While the double-cell regime is sustained, tropical SSTs further decrease over the eastern Indian Ocean and South China Sea (e.g., Fig. $5 \mathrm{~d}$ ), contributing to localization of intense convection over the warm pool region of the western Pacific. Associated with this, low-level westerly anomalies intrude into the western tropical Pacific and anomalous easterlies over the tropical Pacific region retreat eastward (Fig. 4d), being an important trigger of downwelling equatorial Kelvin waves propagating eastward along the equator. The presence of the double-cell regime is necessary for the eastward intrusion of anomalous westerlies into the warm pool region of the western Pacific.

The downwelling equatorial Kelvin waves play a vital role in generating warm SST anomalies over the central and eastern equatorial Pacific because thermocline-SST feedback prevails in a tropical ocean characterized by a shallow thermocline and equatorial upwelling. The SST increase over those regions, together with the SST decrease over the warm pool region of the western Pacific, facilitates an eastward shift of enhanced convection. Associated with the weakening of westerly anomalies over the equatorial Indian Ocean, downwelling equatorial Rossby waves propagate westward to the western tropical Indian Ocean. It is not likely, however, that the subsurface Rossby waves can produce warm SST anomalies over the tropical Indian Ocean because the corresponding region is still covered by cold SST anomalies, as seen in Figs. 6e and 6f. Thus, a reversed single-cell regime is built up due to a reversed anomalous east-west SST gradient between the two oceans. This regime is Phase 3 (late spring to early summer) corresponds to the onset phase of a warm event of ENSO. In this case, wind-evaporation feedback may be more important in controlling the entire tropical Indian Ocean SSTs than the thermoclineSST feedback. Phase 4 (fall to winter) also represents a reversed double-cell regime that corresponds to the mature phase of a warm event.

We stress here that the turnabout of tropical SST anomalies over the central and eastern Pacific occurs in late spring, but over the tropical Indian Ocean it occurs in late summer or early fall. This phase difference is closely linked with the regime shift in the anomalous tropical east-west circulation system from a single-cell to a double-cell regime, and vice versa. When the circulation regime changes from Phase 1 (Phase 3) to Phase 2 (Phase 4), strong (weak) monsoon tends to appear at the late stage of the monsoon season. A necessary condition on which the ES impact operates efficiently is an equatorially symmetric structure of rainfall anomalies over the tropical Indian Ocean accompanied by north-south dipole circulation anomalies in the lower troposphere (see Figs. $4 \mathrm{~b}$ and $4 \mathrm{c}$ ). If the rainfall anomalies in late summer are confined to the vicinity of the equator, the monsoon activity might have been insensitive to anomalous east-west circulation cells over the tropical Indian and Pacific oceans relevant to ENSO. Although it is unclear why a split of the rainfall anomalies into both hemispheres prevails over the tropical Indian Ocean, this phenomenon is supposed to be related to the fact that ENSO-induced SST anomalies are not confined near the equator but expand into the entire region of the tropical Indian Ocean. Conversely, tropical Pacific SST anomalies tend to be confined around the equator due to a substantial contribution of equatorial waves, eventually bringing about localization of rainfall anomalies near the equator. 
Both the South Asian summer monsoon variability and ENSO have an outstanding biennial component prior to the late 1970s. Thus, we should describe the similarities and differences between our possible mechanism presented in Fig. 11 and several important TBO mechanisms (e.g., Meehl 1987; Chang and Li 2000). Meehl (1987, 1993) and Chang and Li (2000) emphasized an active role of the South Asian monsoon system in TBO. They mentioned that anomalous monsoon activity influences anomalous tropical east-west circulation, contributing significantly to the generation of SST anomalies over the equatorial Pacific. In our mechanism, however, the South Asian monsoon system plays only a passive role in anomalous tropical east-west circulation over the Indian and Pacific Ocean regions. We agree with the major role of wind-evaporation feedback in inducing basin-wide anomalous SSTs over the tropical Indian Ocean they pointed out, but the mechanism proposed in this study also requires an active role of ocean dynamics in the central and eastern tropical Pacific. It is suggested that a combination of the wind-evaporation feedback in the Indian Ocean and ocean dynamics in the tropical Pacific is crucially important for the regime shift of the anomalous tropical eastwest circulation system relevant to TBO-like ENSO.

One may wonder if our schematic diagram resembles a conceptual model of TBO proposed by Meehl and Arblaster (2002). However, there are two major differences between the two scenarios. One is the role of land surface conditions on the Asian continent in affecting the monsoon activity. They note the importance of the land surface conditions in the TBO cycle. By contrast, the ES impact does not require the land surface hydrologic processes in the Asian continent. The other is the mechanism of controlling the tropical Indian Ocean SSTs in the TBO. They consider a significant role of ocean dynamics in the tropical Indian Ocean, but in our results equatorial waves do not necessarily play an influential role in generating basinwide SST anomalies over the tropical Indian Ocean. Presumably, surface evaporation and vertical mixing are more important for the basin-wide anomalous SSTs.

Clarke and Shu (2000) postulated that the biennial wind-stress phase-locking in the far western equatorial Pacific accounts for why there is a spring persistence barrier in ENSO. Considering our mechanism, the dominance of their quasi-biennial winds may be regarded a fraction of the regime shift of the anomalous tropical east-west circulation, as illustrated in Fig. 11.

\subsection{Change in the ENSO-monsoon connection before and after the late 1970s}

The Nino-3 SST anomalies tend to persist from preceding winter until early summer after the late $1970 \mathrm{~s}$, as previously stated. This implies that the monsoon variability is likely to be influenced by ENSO forcing at its decay phase. Actually, a dominant precursory signal of anomalous monsoon circulation relevant to ENSO is the presence of equatorially asymmetric anomalies of rainfall and SST over the Indian Ocean in the preceding spring. According to Kawamura (1998) and Kawamura et al. (2001a), a positive wind-evaporation-SST (WES) feedback is crucially responsible for the generation and maintenance of those equatorial asymmetries. Convective forcing off the equator over the warm pool region of the western North Pacific triggers a WES mode in the tropical Indian Ocean through the westward propagation of equatorially asymmetric atmospheric Rossby waves. They also note that this delayed and indirect impact is prominent in early summer, but is not clear in late summer. We term the above precursory signals an equatorially asymmetric (EA) impact of ENSO on the monsoon activity to distinguish it from the ES impact. As inferred from Fig. 1, the EA impact on the monsoon at the decay phase of ENSO cannot strongly regulate the JJAS total rainfall amount over India, although it is quite significant at the early stage (June-July) of the monsoon season during the 15 -yr period 19791993 (see Table 1).

The ES impact at the growth phase of TBOlike ENSO, which is highlighted in this study, brings about the strong ENSO-monsoon coupling prior to the late 1970 s, while the occurrence of the prolonged ENSO after the late 1970s may induce the EA impact on the monsoon at the decay phase of ENSO that is very significant at the early stage of the monsoon season. Compared to the ES impact, the EA impact is indirect and is not persistent until 
late summer. Furthermore, the monsoon after the late 1970s tends to experience both the ES and EA impacts of ENSO although the ES impact becomes less clear. Since the seasonality of ENSO cycle changes before and after the late 1970 s, the difference in the ENSO impacts between its growth and decay phases is considered to influence the ENSO-monsoon relationship. Therefore, we anticipate that a combination of the EA and ES impacts leads to a significant interdecadal change in the ENSOmonsoon connection, associated with the interdecadal modulation of ENSO.

\section{Summary}

Using the NCEP/NCAR reanalysis and an OGCM, we identified a major impact (i.e., equatorially symmetric impact) of ENSO on the South Asian summer monsoon interannual variability. The equatorially symmetric (ES) impact, which is frequently induced by TBOlike ENSO in the Indian and Pacific oceans, tends to prevail during the period from the 1960s to mid-1970s. As ENSO develops, an anomalous east-west circulation system over the tropical Indian and Pacific oceans changes from a single-cell regime in summer to a double-cell regime in fall. Associated with this transition is the prominence of zonally asymmetric SST anomalies between the western and eastern parts of the Indian Ocean in late summer. Low-level twin circulation anomalies across the equator are induced over the tropical Indian Ocean from summer to fall and its northern counterpart is dynamically linked with anomalous monsoon rainfall over India, especially in late summer. Thus, this ENSO impact is clear, especially in late summer. If the TBO-like ENSO regime has a precise biennial periodicity, the summer monsoon season always corresponds to the growth phase of ENSO, which means that the monsoon is always affected by the ES impact. It is also suggested that a combination of the windevaporation feedback in the Indian Ocean and ocean dynamics in the tropical Pacific plays an important role in the regime shift of the anomalous tropical east-west circulation system.

As previously stated, a necessary condition on which the ES impact operates efficiently is a split of rainfall anomalies into both hemispheres over the tropical Indian Ocean (Figs.
$4 \mathrm{~b}$ and 4c). One may argue that such a feature is an artifact because the reliability of the NCEP rainfall is low before the late 1970s. We are aware, of course, that the NCEP rainfall dataset is not based purely on observations. However, an atmosphere-ocean coupled GCM is successful in simulating a similar split of rainfall anomalies over the tropical Indian Ocean as a dominant precursory signal of the transition of a model ENSO (Iizuka et al. 2003). This issue requires further clarification in a subsequent paper.

\section{Acknowledgments}

The authors would like to thank Takio $\mathrm{Mu}$ rakami for a careful reading of the early version of this paper and Yoshiyuki Kajikawa for processing data. Comments by Shang-Ping Xie and two anonymous reviewers were extremely helpful. This research was supported by the research project "Refinement of numerical modeling and technology of global and regional water cycle", and Grants-in-Aids (14540406) of the Japanese Ministry of Education, Sports, Culture, Science and Technology; and by the Mitsubishi Foundation for the Promotion of Science.

\section{Appendix A \\ Explanation of surface fluxes in the model used}

The total surface heat flux $Q_{t o t}$ is calculated using the following formula

$$
Q_{t o t}=Q_{d s w}-Q_{u s w}+Q_{d l w}-Q_{u l w}-Q_{s h}-Q_{l h},
$$

where $Q_{d s w}, Q_{u s w}, Q_{d l w}, Q_{u l w}, Q_{s h}$, and $Q_{l h}$ are surface downward and upward shortwave radiations, surface downward and upward longwave radiations, surface sensible heat and latent heat fluxes, respectively. In this formula, $Q_{d s w}, Q_{u s w}$, and $Q_{d l w}$ are obtained from the NCEP/NCAR reanalysis data. The upward longwave radiation is computed as

$$
Q_{u l w}=\sigma T_{S}^{4}
$$

where $\sigma$ is the Stefan-Boltzmann constant, and $T_{S}$ is the model temperature at the first level. The sensible heat and latent heat fluxes are computed as

$$
\begin{aligned}
& Q_{s h}=-c_{p} \rho C_{h}|V|\left(T_{s}-T_{a}\right), \\
& Q_{l h}=-L \rho C_{h}|V|\left(q_{s}-q_{a}\right),
\end{aligned}
$$



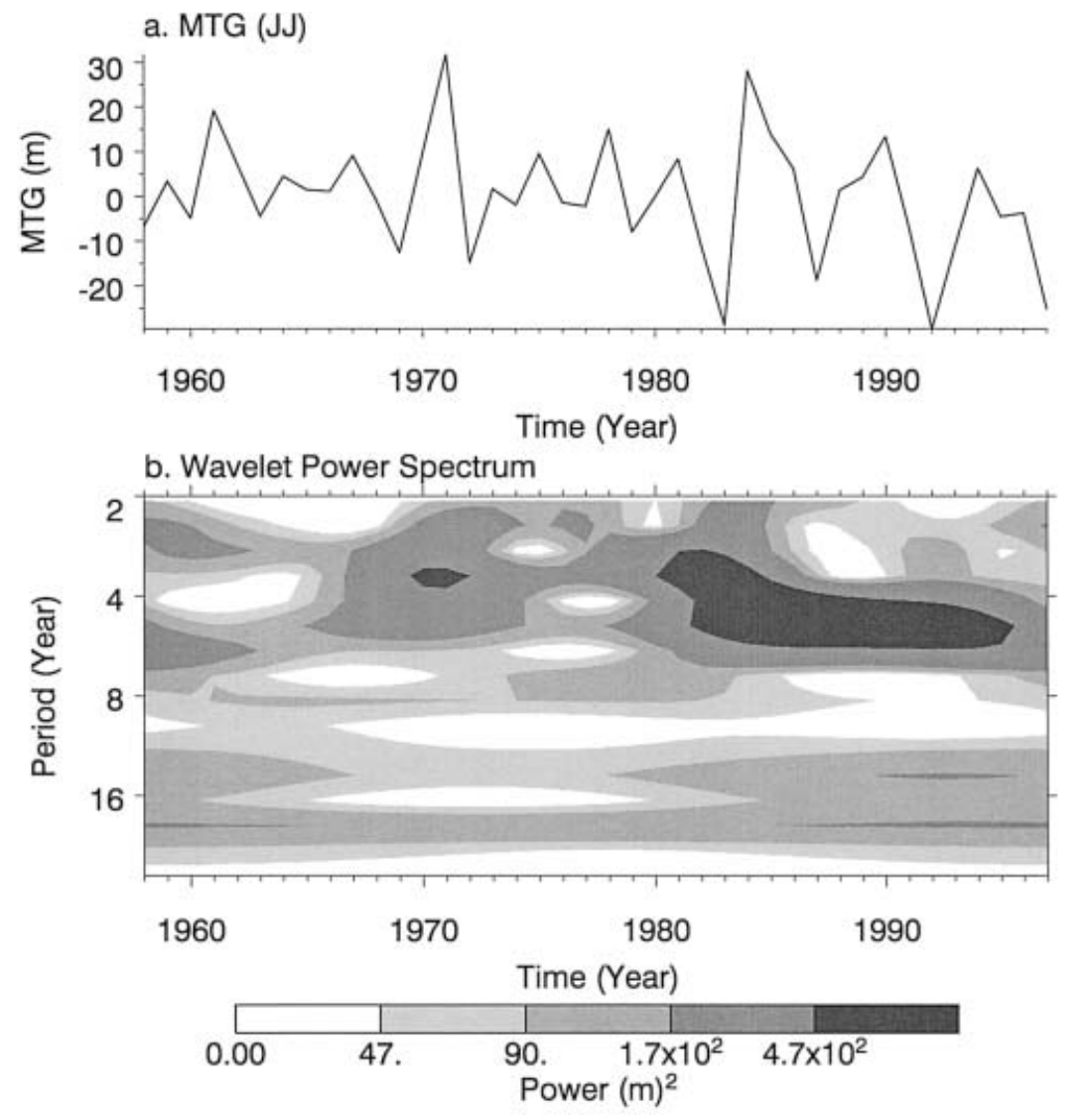

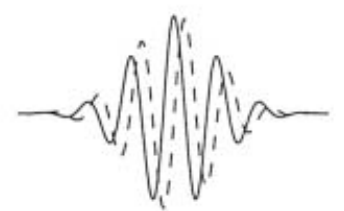

Morlet 6.00

Real (solid) Imaginary (dash)

c. Global Wavelet

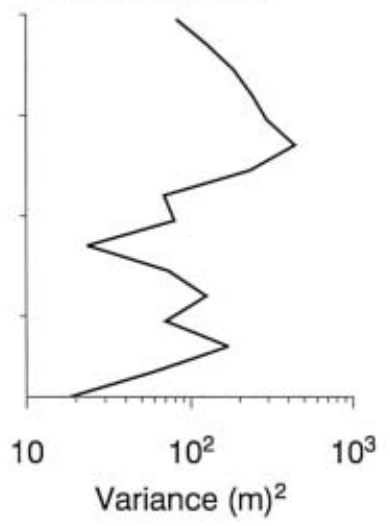

www.ResearchSystems.com

Fig. B1. (a) Time series of MTG (JJ). (b) Its wavelet power spectrum. Shadings are chosen so that $75 \%, 50 \%, 25 \%$, and $5 \%$ of the power is above each level, respectively. (c) The global wavelet power spectrum. These diagrams are plotted using the Interactive Wavelet Plot (http://paos.colorado.edu/ research/wavelets/).

where $c_{p}$ is specific heat at constant pressure, $L$ is latent heat of condensation, $\rho$ is air density, $V$ is wind speed at $10 \mathrm{~m}, T_{a}$ is surface air temperature, $q_{a}$ is surface specific humidity, and $q_{s}$ is saturation specific humidity at the model. In a similar fashion, the surface momentum fluxes are computed as

$$
\begin{aligned}
\tau_{x} & =\rho C_{m}|V| u, \\
\tau_{y} & =\rho C_{m}|V| v,
\end{aligned}
$$

where $u$ and $v$ are zonal and meridional winds at $10 \mathrm{~m}$, respectively. $T_{a}, q_{a}, u$, and $v$ are derived from the NCEP/NCAR reanalysis data. The bulk coefficients $C_{h}$ and $C_{m}$ are estimated according to the similarity function proposed by Louis et al. (1982).

\section{Appendix B \\ Periodicities of JJ and AS mean MTG indices based on a wavelet analysis}

To clearly show that the periodicities of JJ and AS mean MTG indices significantly differ before and after the late 1970s, a wavelet analysis (Torrence and Compo 1998) is performed for both time series (see Figs. B1 and B2). The wavelet power spectrum of MTG (JJ) shows that a 4-5 yr periodicity becomes evident after around 1980, but such a periodicity cannot be seen in that of MTG (AS). It is characteristic that MTG (AS) has a 2-3 yr periodicity during the period from the 1960 s to 1970 s, and a $8-10$ 

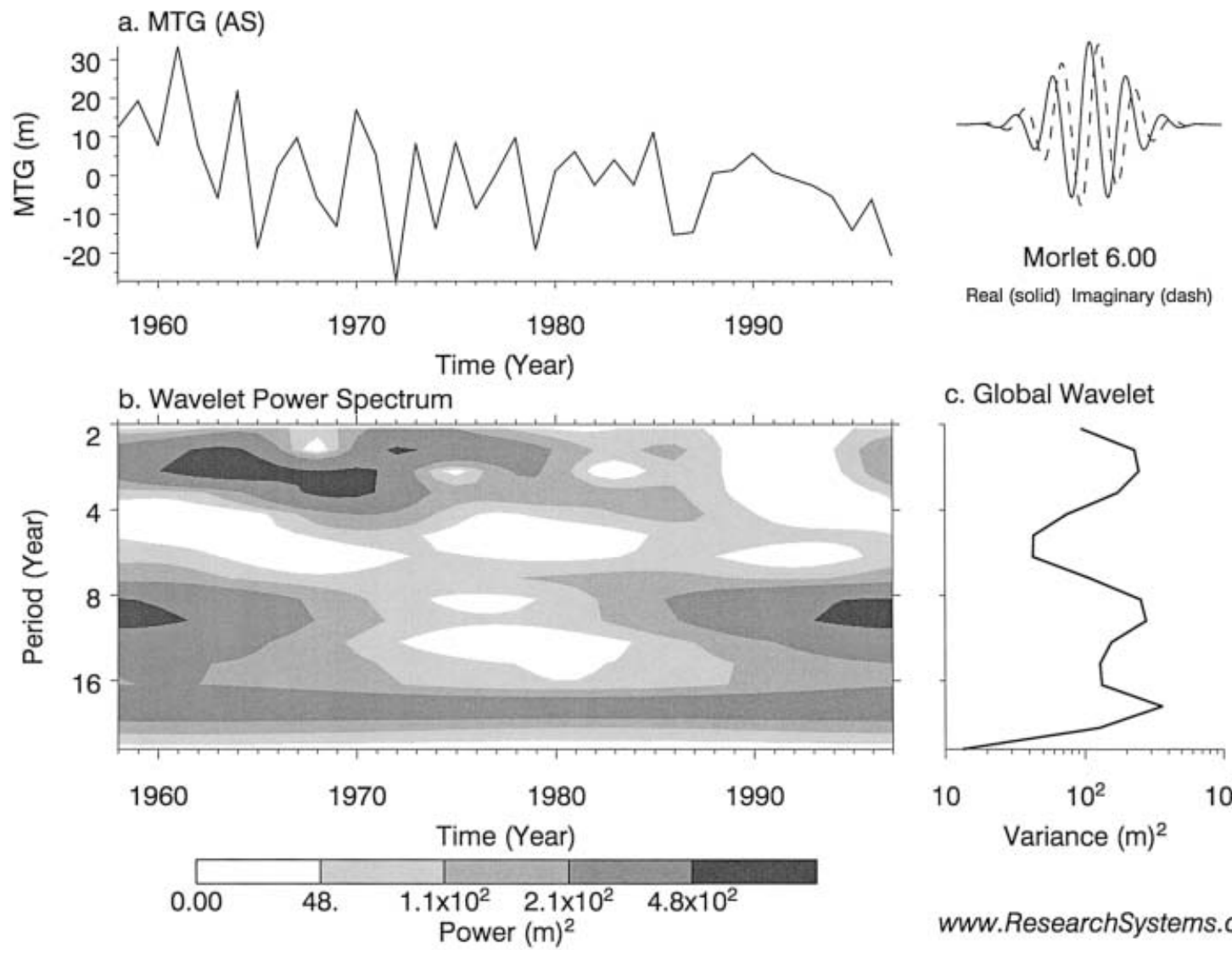

Morlet 6.00

Real (solid) Imaginary (dash)

c. Global Wavelet

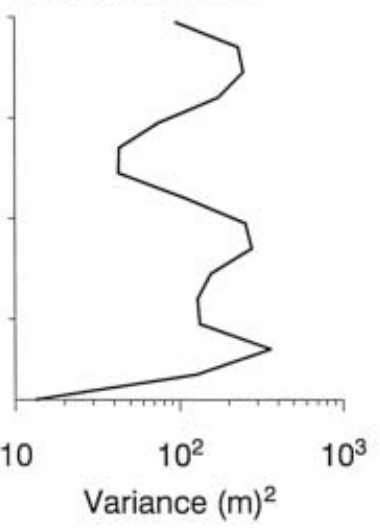

www.ResearchSystems.com

Fig. B2. As in Fig. B1 but for MTG (AS).

yr periodicity is also somewhat significant. Strong contrasting features between MTG (JJ) and MTG (AS) indices suggest that the interannual variability of the South Asian summer monsoon circulation should also be considered on a subseasonal basis.

\section{Appendix C}

\section{Composite anomalies based on another rainfall data}

Using the monthly total precipitation series (V. 1.02) during the period 1950-1999 produced by Cort J. Willmott and Kenji Matsuura (http://climate.geog.udel.edu/ climate/ index.shtml), we made the composite differences in rainfall anomalies between strong monsoon/cold event and weak monsoon/warm event categories (see Fig. C1). Positive rainfall anomalies over both the Indian subcontinent and the maritime continent become significant from JJ to AS. In particular, positive anomalies can clearly be seen along the western coast of its subcontinent because the data used has a fine resolution of $0.5^{\circ} \times 0.5^{\circ}$ grid. From $\mathrm{ON}$ to FM, positive anomalies are located over northern Australia, implying that the Australian summer monsoon is more active than normal, whereas the maritime continent is covered by negative anomalies especially in FM and AM. These composite features are consistent with those obtained by the NCEP rainfall data (Fig. 4). 
(a) JJ RAIN (Willmott \& Matsuura)

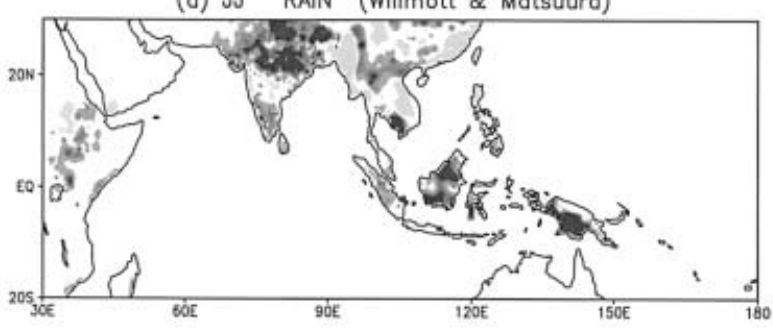

(b) AS RAIN (Willmott \& Motsuura)

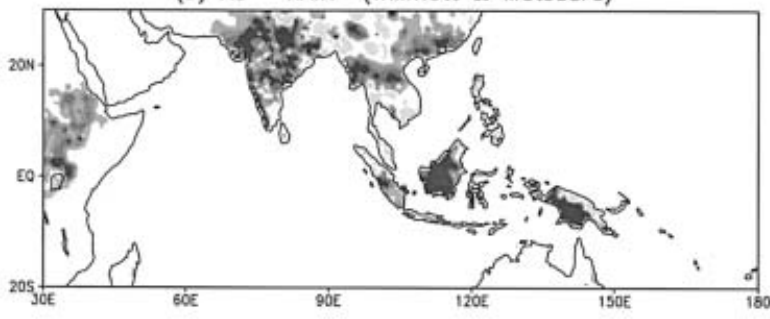

(c) ON RAIN (Willmott \& Matsuura)

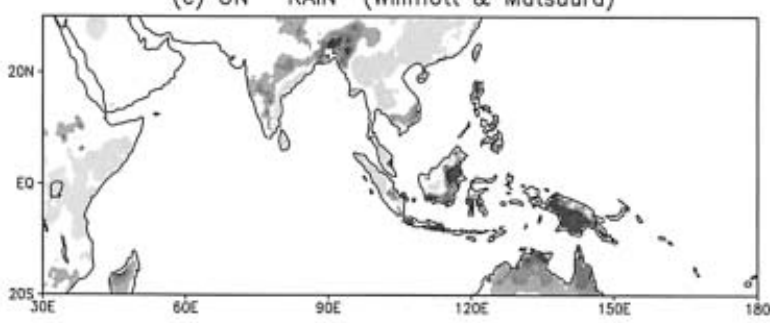

(d) DJ RAIN (Willmott \& Matsuura)

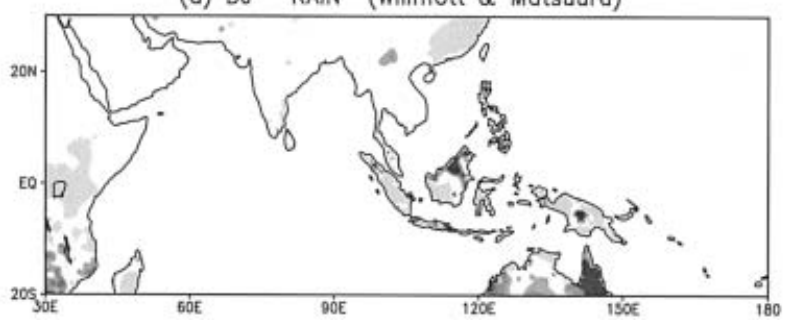

(e) FM RAIN (Willmott \& Matsuura)

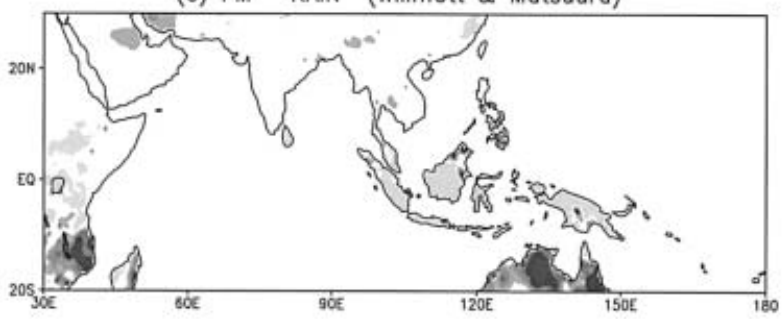

(f) AM RAIN (Willmott \& Matsuura)

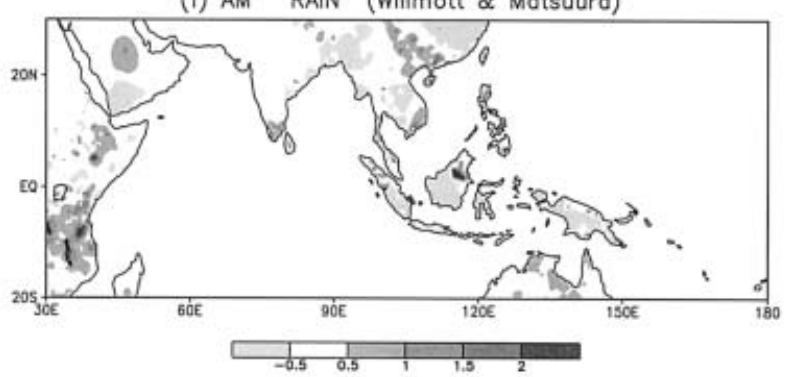

Fig. C1. Composite differences in rainfall anomalies between strong monsoon/cold event and weak monsoon/warm event categories for (a) June-July, (b) August-September, (c) October-November, (d) December-January, (e) February-March, and (f) April-May. The data used are the monthly total precipitation series (V. 1.02) during the period 1950-1999 produced by Cort J. Willmott and Kenji Matsuura. Heavy and light shadings denote significant positive and negative rainfall anomalies, respectively.

\section{References}

Ailikun, B. and T. Yasunari, 2001: ENSO and Asian summer monsoon: persistence and transitivity in the seasonal march. J. Meteor. Soc. Japan, 79, 145-159.

Ashok, K., Z. Guan, and T. Yamagata, 2001: Impact of the Indian Ocean dipole on the relationship between the Indian monsoon rainfall and ENSO. Geophys. Res. Lett., 28, 4499-4502.

Baquero-Bernal, A., M. Latif, and S. Legutke, 2002: On dipolelike variability of sea surface temperature in the tropical Indian Ocean. J. Climate, 15, 1358-1368.

Chang, C.-P., P. Harr, and J. Ju, 2001: Possible roles of Atlantic circulations on the weakening In- dian monsoon rainfall-ENSO relationship. $J$. Climate, 14, 2376-2380.

- and T. Li, 2000: A theory for the tropical tropospheric biennial oscillation. J. Atmos. Sci., 57, 2209-2224.

Clarke, A.J. and L. Shu, 2000: Quasi-biennial winds in the far western equatorial Pacific phaselocking El Nino to the seasonal cycle. Geophys. Res. Lett., 27, 771-774.

Goswami, B.N., V. Krishnamurthy, and H. Annamali, 1999: A broad scale circulation index for interannual variability of the Indian summer monsoon. Quart. J. Roy. Meteor. Soc., 125, 611-633.

Hamada, J.-I., M.D. Yamanaka, J. Matsumoto, S. Fukao, P.A. Winarso, and T. Sribimawati, 
2002: Spatial and temporal variations of the rainy season over Indonesia and their link to ENSO. J. Meteor. Soc. Japan, 80, 285310.

Iizuka, S., T. Matsuura, and T. Yamagata, 2000: The Indian Ocean SST dipole simulated in a coupled general circulation model. Geophys. Res. Lett., 27, 3369-3372.

Iizuka, S., K. Orito, T. Matsuura, and M. Chiba, 2003: Influence of cumulus convection schemes on the ENSO-like phenomena simulated in a CGCM. J. Meteor. Soc. Japan, in press.

Ju, J. and J.M. Slingo, 1995: The Asian summer monsoon and ENSO. Quart. J. Roy. Meteor. Soc., 121, 1133-1168.

Kalnay, E. and Coauthors, 1996: The NCEP/NCAR 40-year reanalysis project. Bull. Amer. Meteor. Soc., 77, 437-471.

Kawamura, R., 1998: A possible mechanism of the Asian summer monsoon-ENSO coupling. $J$. Meteor. Soc. Japan, 76, 1009-1027.

-, M. Sugi, T. Kayahara, and N. Sato, 1998: Recent extraordinary cool and hot summers in East Asia simulated by an ensemble climate experiment. J. Meteor. Soc. Japan, 76, 597617.

, T. Matsuura, and S. Iizuka, 2001a: Role of equatorially asymmetric sea surface temperature anomalies in the Indian Ocean in the Asian summer monsoon and El Nino-Southern Oscillation coupling. J. Geophys. Res., 106, 4681-4693. atmosphere-ocean variations in the tropical western North Pacific relevant to the Asian summer monsoon-ENSO coupling. J. Meteor. Soc. Japan, 79, 883-898.

Kumar, K.K., B. Rajagopalan, and M.A. Cane, 1999: On the weakening relationship between the Indian monsoon and ENSO. Science, 284, 2156-2159.

Lau, K.-M. and H.T. Wu, 2001: Principal modes of rainfall-SST variability of the Asian summer monsoon: A reassessment of the monsoonENSO relationship. J. Climate, 14, 2880-2895.

Lau, N.-C. and M.J. Nath, 2000: Impacts of ENSO on the variability of the Asian-Australian monsoons as simulated in GCM experiments. $J$. Climate, 13, 4287-4309.

and - 2003: Atmosphere-ocean variations in the Indo-Pacific sector during ENSO episodes. J. Climate, 16, 3-20.

Levitus, S., 1982: Climatological atlas of the world ocean. NOAA Prof. Paper 13, 178pp., Natl. Oceanic and Atmos. Admin., Silver Spring, Md.

Li, C. and M. Yanai, 1996: The onset and interannual variability of the Asian summer mon- soon in relation to land-sea thermal contrast. J. Climate, 9, 358-375.

Li, T. and Y. Zhang, 2002: Processes that determine the quasi-biennial and lower-frequency variability of the South Asian monsoon. J. Meteor. Soc. Japan, 80, 1149-1163.

Louis, J., M. Tiedtke, and J.F. Geleyn, 1982: A short history of PBL parameterization at ECMWF, paper presented at the Workshop on Planetary Boundary Layer Parameterization, Eur. Cent. For Medium-Range Weather Forecasts, Reading, England.

Masumoto, Y. and T. Yamagata, 1991: On the origin of a model ENSO in the western Pacific. $J$. Meteor. Soc. Japan, 69, 197-207.

Meehl, G.A., 1987: The annual cycle and interannual variability in the tropical Pacific and Indian Ocean regions. Mon. Wea. Rev., 115, 27-50. , 1993: A coupled air-sea biennial mechanism in the tropical Indian and Pacific regions: Role of the ocean. J. Climate, 6, 31-41.

and J.M. Arblaster, 2001: The tropospheric biennial oscillation and Indian monsoon rainfall. Geophys. Res. Lett., 28, 1731-1734.

- and - 2002: The tropospheric biennial oscillation and Asian-Australian monsoon rainfall. J. Climate, 15, 722-744.

Miyakoda, K., J.L. Kinter, and S. Yang, 2000: Analysis of the connection from the South Asian monsoon to ENSO by using precipitation and circulation indices. COLA Technical Report, $\mathbf{9 0}$, Center for Ocean-Land-Atmosphere Studies, $72 \mathrm{pp}$.

,-- , and 2003: The role of ENSO in the South Asian monsoon and pre-monsoon signals over the Tibetan Plateau. J. Meteor. Soc. Japan, 81, 1015-1039.

Navarra, A., M.N. Ward, and K. Miyakoda, 1999: Tropical-wide teleconnection and oscillation. I: Teleconnetion indices and type I/type II states. Quart. J. Roy. Meteor. Soc., 125, 29092935.

Pacanowski, R.C., 1996: Documentation user's guide and reference manual (MOM2, Version 2). GFDL Ocean Technical Report 3.2, 329pp, Geophys. Fluid Dyn. Lab., Princeton, N. J.

Parker, D.E., C.K. Folland, and M. Jackson, 1995: Marine surface temperature: Observed variations and data requirements. Climate, Change, 31, 559-600.

Parthasarathy, B., A.A. Munot, and D.R. Kothawale, 1995: Monthly and seasonal rainfall series for all India, homogeneous regions and meteorological subdivisions: 1871-1994. Indian Institute of Tropical Meteorology Research Rep. RR-065.

Rao, S.A., S.K. Behera, Y. Masumoto, and T. Yama- 
gata, 2002: Interannual subsurface variability in the tropical Indian Ocean with a special emphasis on the Indian Ocean dipole. DeepSea Res., 49B, 1549-1572.

Rasmusson, E.M. and T.H. Carpenter, 1982: Variations in tropical sea surface temperature and surface wind fields associated with the Southern Oscillation/El Nino. Mon. Wea. Rev., 110, 354-384.

Rosati, A. and K. Miyakoda, 1988: A general circulation model for upper ocean simulation. J. Phys. Oceanogr., 18, 1601-1626.

Saji, N.H., B.N. Goswami, P.N. Vinayachandran, and T. Yamagata, 1999: A dipole mode in the tropical Indian Ocean. Nature, 401, 360-363.

Shaji, C., S. Iizuka, and T. Matsuura, 2003: Seasonal variability of near-surface heat budget of selected oceanic areas in the north tropical Indian Ocean. J. Oceanogr., 59, 87-103.

Schopf, P.S. and M.J. Suarez, 1988: Vacillations in a coupled ocean-atmosphere model. J. Atmos. Sci., 45, 549-566.

Torrence, C. and G.P. Compo, 1998: A practical guide to wavelet analysis. Bull. Amer. Meteor. Soc., 79, 61-78.

Wang, B., R. Wu, and K.-M. Lau, 2001: Interannual variability of the Asian summer monsoon: Contrasts between the Indian and the western North Pacific-East Asian monsoons. J. Climate, 14, 4073-4090.

Wang, B., R. Wu, and T. Li, 2003: Atmosphere-warm ocean interaction and its impact on Asian-
Australian monsoon variation. J. Climate, 15, 1195-1211.

Webster, P.J. and S. Yang, 1992: Monsoon and ENSO: selectively interactive systems. Quart. J. Roy. Meteor. Soc., 118, 877-926.

—, V.O. Magana, T.N. Palmer, J. Shukla, R.A. Tomas, M. Yanai, and T. Yasunari, 1998: Monsoons: Processes, predictability, and prospects for prediction. J. Geophys. Res., 103, 1445114510.

A.M. Moore, J.P. Loschnigg, and R.R. Leben 1999: Coupled ocean-atmospheric dynamics in the Indian Ocean during 1997-1998. Nature, 401, 356-360.

Xie, S.-P., H. Annamalai, F.A. Schott, and J.P. McCreary, 2002: Structure and mechanisms of South Indian Ocean climate variability. J. Climate, 15, 864-878.

Yasunari, T., 1990: Impact of Indian monsoon on the coupled atmosphere ocean system in the tropical Pacific. Meteor. Atmos. Phys., 44, 29-41.

_ 1991: The monsoon year-A new concept of the climate year in the tropics. Bull. Amer. Meteor. Soc., 72, 1331-1338.

$\mathrm{Yu}, \mathrm{L}$. and M.M. Rienecker, 1999: Mechanisms for the Indian Ocean warming during the 19971998 El Nino. Geophys. Res. Lett., 26, 735-738.

Zhang, R.-H. and S. Levitus, 1997: Interannual variability of the coupled tropical Pacific OceanAtmosphere system associated with the El Nino-Southern Oscillation. J. Climate, 10, 1312-1330. 